NBER WORKING PAPER SERIES

\title{
RECESSIONS, OLDER WORKERS, AND LONGEVITY: HOW LONG ARE RECESSIONS GOOD FOR YOUR HEALTH?
}

\author{
Courtney C. Coile \\ Phillip B. Levine \\ Robin McKnight \\ Working Paper 18361 \\ http://www.nber.org/papers/w18361
}

\author{
NATIONAL BUREAU OF ECONOMIC RESEARCH \\ 1050 Massachusetts Avenue \\ Cambridge, MA 02138 \\ September 2012
}

We thank Dan Fetter, Doug Miller, Chris Ruhm, Ann Huff Stevens, and seminar participants at the Boston College Center for Retirement Research, NBER Summer Institute, and Wellesley College for helpful comments. This research was supported by the U.S. Social Security Administration through grant \#5RRC08098400-04-00 to the National Bureau of Economic Research as part of the SSA Retirement Research Consortium. All correspondences regarding this paper should be addressed to Levine. The findings and conclusions expressed are solely those of the authors and do not represent the views of SSA, any agency of the Federal Government, or the National Bureau of Economic Research.

NBER working papers are circulated for discussion and comment purposes. They have not been peerreviewed or been subject to the review by the NBER Board of Directors that accompanies official NBER publications.

(C) 2012 by Courtney C. Coile, Phillip B. Levine, and Robin McKnight. All rights reserved. Short sections of text, not to exceed two paragraphs, may be quoted without explicit permission provided that full credit, including $\odot$ notice, is given to the source. 
Recessions, Older Workers, and Longevity: How Long Are Recessions Good For Your Health? Courtney C. Coile, Phillip B. Levine, and Robin McKnight

NBER Working Paper No. 18361

September 2012

JEL No. I18,J26

\begin{abstract}
$\underline{\text { ABSTRACT }}$
This paper examines the impact of exposure to higher unemployment rates in the pre-retirement years on subsequent mortality. Although past research has found that recessions reduce contemporaneous mortality, these short-term effects may reverse over time, particularly for older workers. If workers experience an economic downturn in their late 50s, they may face several years of reduced employment and earnings before "retiring" when they reach Social Security eligibility at age 62. They also may experience lost health insurance, and therefore higher financial barriers to health care, through age 65, when Medicare becomes available. All of these experiences could contribute to weaker long-term health outcomes. To examine these hypotheses, we use Vital Statistics mortality data between 1969 and 2008 to generate age-specific cohort survival probabilities at older ages. We then link these survival probabilities to labor market conditions at earlier ages. We also use data from the 1980-2010 March Current Population Surveys and the 1991-2010 Behavioral Risk Factor Surveillance System surveys to explore potential mechanisms for this health effect. Our results indicate that experiencing a recession in one's late 50s leads to a reduction in longevity. We also find that this exposure leads to several years of reduced employment, health insurance coverage, and health care utilization which may contribute to the lower long-term likelihood of survival.
\end{abstract}

\author{
Courtney C. Coile \\ Department of Economics \\ Wellesley College \\ 106 Central Street \\ Wellesley, MA 02481 \\ and NBER \\ ccoile@wellesley.edu \\ Phillip B. Levine \\ Department of Economics \\ Wellesley College \\ 106 Central Street \\ Wellesley, MA 02481 \\ and NBER \\ plevine@wellesley.edu
}

\author{
Robin McKnight \\ Department of Economics \\ Wellesley College \\ 106 Central Street \\ Wellesley, MA 02481 \\ and NBER \\ rmcknigh@wellesley.edu
}




\section{INTRODUCTION}

The 2007-2009 recession and the lingering levels of high unemployment in the United States afterwards are the worst since the Great Depression. One might imagine that Americans' health would be adversely affected by the downturn, given the income losses from unemployment. Yet an extensive literature has shown that high unemployment rates are, perhaps counter-intuitively, associated with improved health outcomes. Ruhm (2000) was the first to show that mortality rates actually fall when the economy deteriorates. ${ }^{1}$ Others have confirmed this, including Stevens, et al. (2011) who show that many age groups experience mortality declines during recessions, but that these declines are concentrated among the older population. In this paper, we extend the existing literature to explore the longer-term consequences of recessions, focusing on individuals who are approaching retirement at the time the downturn begins.

Individuals who are approaching retirement when a recession hits may be particularly likely to suffer long-lasting negative consequences. These individuals may have considerable difficulty finding new jobs if job training is viewed as a poor investment for older individuals given their relatively short time horizon in the labor market or if there is discrimination against older workers in the labor market (Lahey, 2008). This may lead to a long period without a job leading up to a retirement that may not be voluntary. The U.S. Government Accountability Office (2012) found that around one-third of unemployed workers over age 55 in 2010 and 2011 had been without a job for over a year. Johnson and Butrica (2012) document that in the latest recession, older unemployed workers were substantially less likely to be re-employed than their younger counterparts. Exploring the link between labor market conditions and retirement over the past thirty years, Coile and Levine (2011a and 2011b) show that recessions are associated with systematically increased rates of

\footnotetext{
${ }^{1}$ In contrast to this finding, Sullivan and von Wachter (2009) indicate that job displacement of long-tenured men increases mortality in both the short and long-term. We describe this work in more detail subsequently.
} 
retirement, particularly at exact age 62, when individuals first become eligible for Social Security retirement benefits. They also provide suggestive evidence that subsequent retirement income may be reduced for these groups, presumably because of the reduced Social Security benefits resulting from early retirement.

Compounding the effects of reduced employment and income, the employer-provided nature of health insurance in the United States suggests that older individuals affected by the recession may lose their health insurance as well. The potentially long duration of their unemployment spells means that the period of lost coverage may be quite lengthy, for some lasting until Medicare eligibility at age 65. The loss of health insurance, and any resulting reduction in health care utilization, could pose a serious health risk for older workers, who often have chronic health problems and frequently experience health shocks such as a heart attack or new cancer diagnosis (Coile, 2004).

Taken as a whole, the lost income during unemployment and retirement, in addition to decreased access to health insurance and health care in the years leading up to Medicare eligibility, could plausibly have a negative long-term impact on health outcomes. In principle, these effects could reverse the contemporaneous health gains that accompany a recession.

The purpose of this paper is to study the impact of recessions on subsequent mortality, focusing specifically on those workers approaching retirement age when the recession hits. We closely follow the empirical strategy in much of the existing literature, using unemployment rates as our key measure of recessions, and relying on variation across states and over time in the unemployment rate to identify their impact. We begin our analysis by constructing state- and agespecific survival rates between the ages of 55 and 79 from Vital Statistics Mortality data for a number of birth cohorts. We use these data to trace out the impact of a higher unemployment rate at each age on contemporaneous survival and on survival at subsequent ages. We go on to explore 
plausible mechanisms that could generate long-term health effects, including employment, health insurance, and health care losses, using data from the 1980 through 2010 March Current Population Surveys (CPS) and the 1991 through 2010 Behavioral Risk Factor Surveillance System (BRFSS) surveys.

Our results indicate that for workers in their late 50s and through age 61, any short-term positive health benefits associated with a recession are temporary and, ultimately, are more than offset by subsequent health deterioration. Interestingly, this pattern is not present for cohorts that face recessions starting at age 62, the age of early entitlement to Social Security. We also find that a recession leads to lengthy periods of unemployment and to financial barriers to health care due to lower rates of health insurance coverage, lasting through the ages of early entitlement to Social Security and Medicare eligibility, respectively. Our results suggest that these programs might buffer the long-term negative health consequences of recessions. Although we cannot definitively determine that reduced employment, insurance coverage, and health care use are the mechanisms underlying our mortality findings, we view all of them as plausible. Regardless of the mechanism, our findings underscore the fact that the contemporaneous effect of recessions on health - which has been the focus of a substantial and important literature - is only part of the story. For those who are approaching retirement when a recession hits, an economic downturn can have long-lasting effects that more than offset the well-known contemporaneous health benefits of recessions.

\section{LITERATURE REVIEW}

As we briefly referenced earlier, a substantial body of research has emerged that focuses on the contemporaneous effect of economic conditions on health outcomes. Ruhm (2000) was the first entry into this literature, showing that mortality rates fall when the economy deteriorates. This finding holds for a broad range of causes of death, including heart disease, flu and pneumonia, 
vehicle accidents, and infant and neonatal mortality. In subsequent work, Ruhm (2003) shows that economic downturns improve other measures of health, such as the prevalence of chronic conditions, and Ruhm (2005) shows that higher unemployment is related to reduced smoking, increased physical activity, and reduced obesity. ${ }^{2}$

More recent work by Miller et al. (2009), however, argues that the observed short-term effect of economic conditions on mortality must be driven by external factors rather than by changes in health behaviors among job losers, because the mortality effects are largest among the elderly population, which is unlikely to be directly affected by unemployment. Stevens et al. (2011) extend this work, providing evidence that improved nursing home staffing during recessions may be an important mechanism for the improved mortality among the elderly. All of these papers focus on the contemporaneous impact of high unemployment and do not address the potential long-term impact on health outcomes.

The long-term impact of job loss on displaced workers is examined by Sullivan and Von Wachter (2009), who present evidence that job loss is associated with both higher short-term and long-term mortality. They find that, even twenty years after losing a job, displaced workers continue to have higher mortality rates. The authors posit that the long-term mortality effect that they observe among displaced workers may be attributable to the long-term reduction in earnings associated with job loss. These findings are an interesting counter-point to the rest of the literature, because they indicate that, even if recessions improve health on average, there are important subpopulations for whom recessions may worsen health. They also raise the possibility that the short-term mortality

\footnotetext{
${ }^{2}$ Several recent studies have also examined the impact of recessions on health-related behavior. For example, using data from Iceland, Asgeirsdotter et. al. (2011) find that the Great Recession led to reductions in health-compromising behaviors and increases in some health-promoting behaviors. In the United States, using data from the American Time Use Survey, Aguiar et. al. (2011) find that unemployment is associated with more time spent on TV-watching and sleeping, as well as home production and leisure activities.
} 
gains that are present on average could be offset over time, as the contemporaneous benefits of recessions on non-workers dissipate and the long-term effects of job loss on a subset of the population becomes more prominent. Reconciling our findings with those from these two disparate streams of research is a critical task that we undertake subsequently.

A related literature focuses on the impact of income changes on the health status of retirees. Snyder and Evans (2006) examine the impact of the "Social Security notch" on the mortality rates of retirees. The Social Security notch was created by a mistake incorporated into legislation that led to the double indexation of Social Security benefits to inflation. When the mistake was fixed, it led to a "notch," where a certain cohort of retirees received lower Social Security benefits than those retirees who immediately preceded them. Snyder and Evans find that additional income in retirement leads to higher mortality rates and they argue that social isolation among retirees may be responsible. Although this analysis provides an interesting experiment related to the effects of an income shock, the shock generated by an unemployment spell may not necessarily have the same impact.

In related work focusing on recessions and older workers, Coile and Levine (2010, 2011a, and 2011b) address the impact of a weak labor market on retirement decisions and subsequent retiree income. They find that higher unemployment leads older workers to "retire" (i.e. completely withdraw from the labor force) beginning at age 62. This suggests that Social Security may provide a lifeline to older workers who experience an employment shock, struggle to find new work, and finally withdraw from the labor force (albeit with reduced benefits) once they make it to that age. Consistent with this evidence, they also provide suggestive evidence that subsequent Social Security income is lower when unemployment is high in the period leading up to retirement. These results indicate that approaching retirement at the time of a recession can have important consequences for 
subsequent labor market activity and income. An obvious extension of this work is to examine whether approaching retirement at the time of a recession also has health effects.

\section{EFFECTS ON MORTALITY}

\section{A. Empirical Approach}

Our empirical strategy is designed to build on the foundations set by Ruhm (2000, 2003, 2005a, and 2005b), Miller, et al. (2009), and Stevens, et al. (2011), all of whom use the same basic methodological framework for their analyses. Specifically, they estimate regression models of the form: ${ }^{3}$

$$
\ln M_{j t}=X_{j t} \cdot \beta+U R_{j t} \cdot \gamma+\alpha_{t}+\phi_{j}+\phi_{j} T+\varepsilon_{j t}
$$

where $\ln \mathrm{M}$ is the natural $\log$ of the mortality rate in state $\mathrm{j}$ and year $\mathrm{t}, \mathrm{X}$ is a vector of demographic controls, and UR is the state unemployment rate. The vector of year specific fixed effects, $\alpha_{t}$, captures national time effects, and the vector of state specific indicator variables, $\phi_{j}$, controls for time-invariant state characteristics. State-specific time trends, $\phi_{j} \mathrm{~T}$, are also included. The main source of identification in this model is state and year level variation in the unemployment rate. A specification like this is the starting point for our analysis; as we show subsequently, we are able to largely replicate the main features of the results from these previous studies.

We then extend this approach by altering the focus from a point-in-time analysis to a lifecycle analysis. As described earlier, our goal is to estimate the long-term health effects associated with experiencing a recession in the period leading up to retirement. We introduce an empirical specification that begins with the contemporaneous positive health shocks that occur in response to a rise in unemployment and then examines whether those effects persist, fade away, or

\footnotetext{
${ }^{3}$ This notation is largely the same as in Stevens, et al. (2011), but has been modified slightly to clarify the distinctions between their model and the one we specify subsequently.
} 
even reverse course over time. To estimate these dynamic effects, we revise the estimation strategy to focus on the probability of survival as one ages as a function of the labor market shock experienced in an earlier period. As we move to survival analysis, the relevant form of data switches from pooled cross-sections to cohorts. We aim to answer the question: what was the effect on subsequent survival of nearing retirement in differing economic environments?

The model we estimate to formally incorporate these ideas takes the form:

$$
S_{j c a}=U R_{j c A} \cdot \gamma_{A a}+\alpha_{c}+\phi_{j}+\phi_{j} T+\varepsilon_{j c a}
$$

The first main change as we move from Equation (1) to Equation (2) is that the dependent variable is now the survival probability (S), measured in levels, not in logs. If we are to track the absolute impact on survival over time (i.e. determine whether the positive immediate impact on survival returns to zero or even turns negative over time), survival rates in levels are the appropriate outcome.

Second, we are still indexing observations by state of residence, $\mathrm{j}$ (although we will provide additional discussion of this subsequently), but now we are tracking cohorts, c, measured at different ages, a, starting from age A, the year in which the shock occurs, and continuing to age 79, the oldest age at which we track survival probabilities. In other words, if a particular cohort experiences an increase in the unemployment rate at, say, age 60 (age A), what impact does that have on survival probabilities between ages 60 and 79 (ages a)? Note that when a = A (i.e. at age 60), this model is very similar to Equation (1), where the probability of survival through age 60 is one minus the mortality rate in that year. This interpretation also highlights why the coefficient on the unemployment rate, $\gamma$, is subscripted by A and a, because the impact of the age 60 unemployment rate is estimated for survival to ages 60 through 79, or 20 times.

A third difference between this specification and Equation (1) is that we have dropped population characteristics, labeled $\mathrm{X}$ in the earlier model. We made this decision partly because it is 
not clear at what age to capture those characteristics in the context of a survival model and partly because of issues in gathering these data; no obvious source provides large samples at each exact age over the relevant time period. As we show subsequently, omitting those explanatory variables from Equation (1) does not alter the qualitative nature of earlier findings.

Fourth, we have changed our notation to indicate that we are controlling for cohort fixed effects $\left(\alpha_{c}\right)$ rather than year fixed effects $\left(\alpha_{t}\right)$ because this is a cohort-based model. This change is merely a notation change and is not empirically relevant, since these age-specific regressions make year fixed effects identical to cohort fixed effects.

Our approach has the advantage of allowing us to confirm earlier findings and then extend them to focus on our question, but it comes with disadvantages as well, which are largely a result of data limitations. The first limitation is our inability to track migration as people age. Our goal is to estimate the effect of a one percentage point increase in the age 60 unemployment rate in, say, Missouri, on an individual's subsequent survival. Unfortunately, however, we can only determine state of residence at the time of death from our data, not state of residence at some earlier age. If the Missourian moved to Florida at, say, age 68, we would inadvertently associate her death with the Florida cohort and not the Missouri cohort. Migration at these ages is reasonably prevalent, particularly in some states. Using data from the 1980, 1990, and 2000 Censuses, we estimate that 5 percent of those between the ages of 60 and 70 moved across state lines in the preceding five years. For those residents of Arizona and Florida at these ages, 20 and 12 percent, respectively, lived in a different state five years ago.

Although it would be ideal to perfectly track state of residence over the relevant age ranges, we do not believe that this limitation will substantively alter the results of our analysis. First, migration to improve one's job-finding prospects seems unlikely at these ages, so movement 
between states is likely to introduce classical measurement error that would introduce a downward bias in our estimates. To the extent that we obtain results that are statistically different than zero, then this is just an understatement of the true effect. Second, we have re-estimated all the models reported below excluding Arizona and Florida, the main states that experience substantial migration inflows, and we obtained very similar results.

A second limitation of our approach is that the data requirements are formidable. We define "nearing retirement” as being between the ages of 55 and 65. Our goal is to track survival probabilities through age 79. This means that we need to calculate survival probabilities for upwards of 25 years for each cohort, which requires mortality data in each of those years. Although we have available the universe of death certificates from the United States Vital Statistics system, these data are available beginning only in 1968 and through 2008 at the time of this analysis. ${ }^{4}$ Population data by state and exact age are available (from the National Cancer Institute, available at seer.cancer.gov) beginning only in 1969, making that the first year for which we can calculate survival rates. We focus on the 1910 through 1929 birth cohorts, for whom we are able to calculate a complete set of survival rates for ages 59 through 79 (the 1910 birth cohort was age 59 in 1969 and the 1929 birth cohort was 79 in 2008). To expand the age range to earlier ages, we must reduce the number of cohorts we examine. For instance, to start the survival analysis at age 58, the 1911 birth cohort is the first one we can use. To go back to an age 55 starting age, we focus on the 1914 through 1929 birth cohorts. We prefer this approach (using a slightly smaller number of cohorts when examining

\footnotetext{
${ }^{4}$ State identifiers in Vital Statistics Mortality data are available publicly through 2004, but then require permission from the Centers for Disease Control to use them in more recent years. These more recent data are treated as confidential and we are unable to share them.
} 
survival rates at ages 55 to 59 but making use of the 1910 through 1914 cohorts in the rest of the analysis) because of the additional power available. ${ }^{5}$

One additional consideration in the specification of this model is the inclusion of the unemployment rate associated with the base age (A) only. In theory, survival in each year between, say, ages 60 and 74 might be affected by the unemployment rates in each of the intervening 15 years. Our specification omits the unemployment rates in the intervening years, focusing on labor market conditions at the base age (i.e. age 60). Our decision to exclude all of these other unemployment rates was made to focus on the subsequent effect of an initial shock. Unemployment rates tend to be serially correlated over short periods of time, but not over longer periods of time. ${ }^{6}$ This means that excluding a considerably more recent unemployment rate (i.e. excluding the age 70 unemployment rate in a specification focused on the effect of unemployment at age 60) will not introduce omitted variable bias in the coefficient on the base age unemployment rate, while including it will reduce the precision of the estimate. We chose to omit the unemployment rate from neighboring years (i.e. the age 61 unemployment rate) because it will be serially correlated with the base age unemployment rate, standard errors will be inflated, and we will have difficulty interpreting the results. If we include only the age 60 unemployment rate, part of the effect we estimate may be capturing the fact that the high unemployment rate lingered for another year. We do not view this as being

\footnotetext{
${ }^{5}$ We have also estimated all models using the smaller sample of 1914 through 1929 birth cohorts for survival between ages 55 and 79 as well as the 1914 through 1933 birth cohorts for survival between ages 55 and 75 . In each case, we obtained qualitatively similar results (which are available upon request).

${ }^{6}$ In a simple analysis, we find that a state unemployment rates is positively related to unemployment rates in the same state from each of the prior three years, after controlling for state fixed effects and year fixed effects. Not surprisingly, the relationship is strongest for the unemployment rate in the immediate prior year. This relationship does not hold for unemployment rates that are more than three years apart.
} 
problematic for our purposes, as it is the cumulative effect of a recession that we are trying to capture. $^{7}$

This discussion clarifies the nature of the data we use in this analysis. As we already highlighted, we use Vital Statistics Mortality microdata between 1969 and 2008, making use of the age at death, the birth year, and the state of residence. We augment this with the SEER estimated population data by state and age from the National Cancer Institute to create annual mortality rates by birth cohort and state of residence. We treat state of residence as a constant. This enables us to convert these mortality rates to survival rates; we do this for the 1910 through 1929 birth cohorts and estimate survival from ages 59 through 79. We estimate survival rates beginning at ages 55, 56, 57, and 58 by restricting the birth cohorts further, starting in 1914, 1913, 1912, and 1911, respectively. State unemployment rates are available from the Bureau of Labor Statistics starting in 1976. For earlier years, we use the state unemployment rates available from the U.S. Department of Labor in their series, Manpower Reports of the President (various years). ${ }^{8}$

\footnotetext{
${ }^{7}$ To further address this specification issue, we estimated analogous models as in equation 2, but we aggregated the unemployment rate into averages over three year windows (starting with age 55-57 average unemployment and survival through age 57). We replicated the specification in equation 2 using these averaged unemployment rates and we obtained similar results to those reported below. Then we continued including average unemployment rates over subsequent three year intervals (i.e. at 58-60, 61-63, 64-66, ...) to examine the impact of the full time series path of labor market conditions, but reducing the influence of serial correlation. As we add unemployment rates at subsequent ages in the model, our estimates on the base period unemployment rate become somewhat less precise, but the magnitudes are similar to those we report below. The coefficients on the unemployment rates at subsequent ages, however, start becoming erratic as more years of unemployment rate data are included (these results are available on request). We believe that these results affirm our more parsimonious model specification.

${ }^{8}$ The source of state unemployment rates from Manpower Reports of the President in the years earlier than 1976 is not clear. The only detail provided in these reports are table notes indicating their source as "state employment security agencies cooperating with the U.S. Department of Labor.” To assess the value of these data, we have compared their means to national averages, compared state patterns/values in the years just before 1976 to values just after, examined cyclical patterns by state (looking for greater cyclical responsiveness in Michigan, for instance), and compared their values to measures of the insured unemployment rate (which are traditionally lower). All of these comparisons suggest that these data represent meaningful measures of labor market conditions in a state that are comparable to BLS data for subsequent years. We have also conducted our analyses using only data beginning in 1976 and obtained results that were qualitatively similar, although less precise, than those we report here.
} 


\section{B. Replication Exercise}

Before presenting the results of our survival analysis, we first present Table 1, which shows the results of our replication analysis addressing contemporaneous mortality based on the work of Stevens, et al. (2011). ${ }^{9}$ We begin by attempting to replicate the results that Stevens, et al. present in their Figure 2, which displays the impact of a one percentage point increase in the unemployment rate on contemporaneous mortality by exact age. ${ }^{10}$ Replicating their results by exact age is appropriate since the remainder of our analysis focuses on outcomes by exact age. To reduce the amount of material to report, in Table 1 we have chosen to provide the results at exact ages between 55 and 75 in five year intervals. The first two columns of the table provide mean mortality rates over the 1969 through 2008 sample period (Column 1) and for the 1910 through 1929 birth cohorts (Column 2) at each age. These statistics are presented for purposes of comparison with coefficient estimates presented subsequently to provide some context for their magnitude.

We begin reporting the results of our replication attempt in Columns 3 and 4, which display the results from Stevens, et al. (2011), and our attempt to replicate those estimates. As the second line of the table indicates, we use the 1978 through 2006 sample years for all available birth cohorts in those years, as they do. Our findings are not identical to theirs, but the differences are very small; in each case, they differ by less than 0.1 of a standard deviation. Based on this, we are confident in proceeding. ${ }^{11}$

\footnotetext{
${ }^{9}$ Stevens, et al. (2011) also successfully replicated the findings in Ruhm (2000), making our analysis a third generation replication.

${ }^{10}$ We are grateful to the authors of this paper for sharing the publicly available parts of their data with us along with their detailed results so that we could have access to the exact coefficients and standard errors for the points listed in their Figure 2.

${ }^{11}$ After examining our underlying data (through 2004, since subsequent data are confidential) and statistical code, we are able to detect very small differences in the data in both population counts and the number of deaths beginning in the year 2000. This is likely attributable to minor revisions in these data that were made between the times they were downloaded for use in the two studies.
} 
The remainder of the table is designed to translate our specification from that expressed in Equation (1) to that expressed in Equation (2). As we described earlier, it is unclear how to incorporate the explanatory variables (other than the fixed effects) in a longitudinal analysis, so the next thing we do is test the sensitivity of our results to dropping these variables. The results in Column (5) are similar to those in Column (4), so we do not believe that we are imparting bias by dropping these variables. In Column (6) we extend our sample to include mortality and labor market outcomes between 1969 and 2008, adding nine years of data before and two years of data after that used by Stevens, et al. This change has a bigger impact on the results. In general, we observe a stronger negative relationship between unemployment and mortality; the magnitude of these differences is up to a full standard deviation. The sensitivity of the results to the sample period is a finding that Stevens, et al. (2011) report as well, so we are not surprised by this finding.

The next change that we make is to restrict the data to focus on the 1910 through 1929 birth cohorts. Those results are reported in Column (7). For the most part, this alteration does not have much of an impact other than to inflate standard errors somewhat, as one would expect when we reduce the amount of data used in estimation. The one change of significance is observed for mortality at age 75. For workers at that age, focusing on the 1910 through 1929 birth cohorts eliminates a negative and statistically significant impact. One possible cause of this is that these birth cohorts hit age 75 between 1985 and 2004. This means that these cohorts did not experience the major recession of the early 1980s at that age, meaning that the variation in the data used to estimate this model is largely based on the two mild recessions in the early 1990s and early 2000s. If we replicate the Stevens, et al. model using post-1985 data, we similarly observe a large reduction in the point estimate. As a result, we believe that this sensitivity is also attributable to the sample window used for estimation. 
The final change that we make in Column (8) is to convert the dependent variable from mortality measured in logs to levels. This change has very little impact on the results. This can be seen by comparing t-statistics between Columns (7) and (8) or by comparing the ratio of the Column (8) to Column (2) statistics to create percentage change effects and then comparing that to the results in Column (7). Either way, it is clear that estimating the model in levels or logs provides the same substantive results. The results in column (8), which show the same basic pattern of results as the previous literature on the contemporaneous effects of recessions, constitute estimates of Equation (2) for five cases where $A=a$. These results are the starting point for our analysis of long-term survival effects.

\section{B. Results of Survival Analysis}

This section reports the results of estimating statistical models of the form represented by Equation (2). In order to better interpret these findings, we first present some descriptive statistics on aggregate survival rates beginning at age 55 and continuing through age 79 . The age 55 survival rate is the probability of surviving through age 55 conditional on having survived up to age 55, so it is a number slightly less than one. Survival rates at subsequent ages are the probability of surviving through that age conditional on surviving up to age 55. Appendix Table 1 provides a full set of survival probabilities. For simplicity, we present in Figure 1 these survival rates for the 1915 and 1925 birth cohorts to demonstrate not just the patterns by age, but the general patterns across cohorts as well. Among members of the 1915 birth cohort who survived to age 55, the probability of surviving to age 79 is 49.7 percent. Members of the 1925 birth cohort live longer, unsurprisingly, surviving to age 79 at the rate of 54 percent.

The full set of results from estimating Equation (2) is presented in Appendix Table 2. The number of regressions that are inherent in that model is somewhat overwhelming. For 
unemployment shocks experienced at each age between 55 and 79, we estimate the impact on survival probabilities at each age between the base age and age 79. This means that our full set of results contains 435 regressions. Even reporting just the key unemployment rate coefficient and its standard error from each regression is overwhelming in any traditional format.

Instead, we adopt the following approaches to reduce the extent of reporting. First, we provide Appendix Table 2, which reports a complete set of results for all models in which the unemployment shock is measured between ages 55 and 65. These are the ages leading up to retirement that are the focus of this analysis. Second, we present two figures that show coefficients from selected regressions and are designed to capture the critical features of these results. Estimated effects that are statistically significant at the 5 percent level are indicated by diamonds on the figures.

Figure 2 displays the contemporaneous effects, meaning the impact on current age survival of an increase in the unemployment rate at that age. This analysis is virtually identical to that reported for selected ages in Column 8 of Table 1 (although mortality there is converted to survival here, so negative mortality effects become positive survival effects). These results indicate that higher unemployment increases survival probabilities across all of our age groups at a roughly similar rate. Specifically, a one percentage point increase in the unemployment rate increases one-year survival probabilities by around 0.0005 , or by 0.05 percentage points. With mortality rates that average around three percent, this 0.05 percentage point increase in the one-year survival rate reflects about a 1.7 percent decrease in mortality rates. A larger impact is observed around age 70. Again, these results are generally consistent with the findings in Stevens, et al., with perhaps the exception of those in their late 70s. As described earlier, this exception is likely a result of different sample periods. 
Figure 3 displays the long-term effects, meaning the impact of an increase in the unemployment rate at some specified age on the path of survival rates from that age through age 79. Rather than provide these effects for unemployment rate increases at each possible age, which would be overwhelming, we selected five specific base ages $(55,58,60,62$, and 65$)$ that provide an adequate characterization of the complete set of results. Note that the first point on each line is the contemporaneous effect, as reported in Figure 2 for the relevant age. Other points on the line show subsequent effects on survival, as measured at the ages that are denoted on the horizontal axis. To condense the necessary content of these figures as much as possible, we again use a diamond on each line to reflect those effects that are statistically significant at the 5 percent level.

As we reported in Figure 2, the contemporaneous effects are typically small and positive, indicating that survival rates increase when the unemployment rate goes up. None of these contemporaneous effects displayed are statistically significant, but Figure 2 shows that they are at some ages. One interesting extension of these results is that the positive effect on survival probabilities may even increase in the few years following the rise in unemployment.

The issue upon which we would prefer to focus, however, is what happens subsequently, and particularly as workers age into their retirement years. For those who experience a weaker labor market at age 55, the positive impact on survival quickly fades and becomes insignificantly different from zero through their 70s. Similarly, for those who experience higher unemployment at ages 62 and 65, we see no statistically significant longer-term impact on survival. For those who experience a weak labor market at ages 58 or 60, however, an increase in the unemployment rate has long-term deleterious effects on survival probabilities. Within five or so years after the labor market shock, 
these cohorts have lower survival rates than others who did not experience a shock, and those lower survival rates are statistically significant and continue throughout most, if not all, of their 70s. ${ }^{12}$

The magnitude of these effects indicates that a one percentage point increase in the unemployment rate when an individual is in his or her late 50s reduces the probability of survival into his or her 70 s by 0.0003 to 0.0004 percentage points. A major recession that increases the unemployment rate by 5 percentage points (as we experienced in the early 1980s and in 2008), would have a 0.0015 to 0.0020 percentage point impact on survival. Although these effects might appear to be incredibly small, it is important interpret them within the context of the number of workers who lose their jobs during a recession, the number who may lose health insurance, and then the number of those whose health may be seriously affected as a result. We place these estimates into this broader context subsequently.

\section{EFFECTS ON HEALTH CARE USE, HEALTH INSURANCE, AND EMPLOYMENT}

\section{A. Data and Empirical Strategy}

In this section of the paper, we explore potential mechanisms for the long-term increase in mortality associated with recessions that occur when cohorts are in their late 50s and very early 60s. We specifically examine the short- and long-term impacts of recessions on access to health care, health insurance coverage and labor market outcomes. The best data source for examining insurance coverage and employment over a long period of time is the March CPS; we pool data from the 1980 to 2010 surveys for our analysis. Although the CPS is available for earlier years, health insurance variables are not defined consistently prior to 1980, so we choose to limit our sample to these 31

\footnotetext{
${ }^{12}$ We have examined these effects separately by gender and find that the point estimates are very similar for males and females. We would prefer to also distinguish the data by level of education, but we are unable to do so since Vital Statistics mortality data only began recording the education level of the deceased in 1989 and because population estimates by exact age, state, and education level are not available to be able to create the mortality rates that serve as inputs to the survival rate. We also considered incorporating cause of death into the analysis, but our focus on survival rather than mortality complicates such an analysis.
} 
survey years. ${ }^{13}$ For health care use, we provide evidence from the BRFSS, pooling the 1991-2010 survey years for our analysis. While the BRFSS survey collects more information on health behaviors than on health care utilization, it does include a question about whether, during the past 12 months, the respondent needed to see a doctor, but did not because of cost. We use this question to construct our key measure of health care access/use. ${ }^{14}$

Ideally, we would use exactly the same empirical strategy examining these outcomes as we did for mortality in the previous section. Those regression models, however, impose formidable data requirements. We were able to meet those requirements in our analysis of survival probabilities, because of the availability of Vital Statistics data, which include the universe of deaths. In contrast, survey data sets such as the BRFSS and CPS introduce some limitations and therefore require modifications to our empirical strategy.

The first limitation is that we are no longer able to follow a fixed panel of birth cohorts, as we do in Vital Statistics data. The BRFSS and CPS both provide repeated cross-sections so, of course, we are not able to follow the same individuals as they age from their 50s into their 70 s. In addition, we could only follow a small number of fixed birth cohorts over the twenty year period from their 50s into their 70s. For example, we could follow only the 1925 through 1932 birth cohorts in the 31 years of Current Population Surveys. Therefore, we choose to include all observations between the ages of 53 and 79 who appear in these surveys, regardless of birth cohort. ${ }^{15}$

\footnotetext{
${ }^{13}$ Even within these 31 survey years, health insurance variables are not entirely consistent. We have tested the sensitivity of our results to using a narrower sample period with more consistently-defined measures of health insurance. We obtain qualitatively similar results, but with less precision.

${ }^{14}$ We have also examined health care utilization variables (and health outcome measures) in the National Health Interview Survey (NHIS) and the BRFSS, including outcomes like doctor visits in the past 2 weeks and hospital days. Unfortunately, it became obvious to us that these sources of data did not contain sample sizes large enough to provide the necessary power to draw strong conclusions from these analyses.

${ }^{15}$ For some of the observations on the oldest individuals in the 1980 through 1985 CPS surveys, we do not observe the unemployment rates that they faced in their early and mid-50s, because our unemployment data do not extend earlier than 1960. We have re-estimated our CPS regressions excluding the 1980-1985 surveys and find that our results are not
} 
The second limitation is that these data sets are too small to precisely identify the impact of the unemployment rate at a single age on outcomes at a single age. Therefore, we pool the data into nine three-year age groups, from ages 53-55 to ages 77-79. We calculate the average unemployment rates for a cohort and state across each three-year age group and use that average as the key independent variable in our regressions. Our regression equation builds on that in Equation (2), but incorporates these modifications. It takes the form:

$$
Y_{i j t g}=U R_{j t G} \cdot \gamma_{G g}+\delta_{t}+\phi_{j}+\phi_{j} T+\lambda_{a}+\varepsilon_{i j t g}
$$

where $Y$ is an outcome, such as insurance coverage or employment, for individual $i$ in age group $g$ in state $j$ and year $t$. $\mathrm{UR}_{j t G}$ is the average unemployment rate that would have faced an individual in state $j$ and survey year $t$ when they were in age group $G$. The regression is estimated separately for each combination of age groups $g$ and $G$. Like the survival models, these regressions control for a full set of state fixed effects and state-specific linear trends. Whereas the survival regressions included cohort fixed effects, these regressions include survey year fixed effects. The only other difference is that these regressions include fixed effects for the exact year of age, $a$, since each regression includes three ages. The key regressors of interest are the $\gamma_{g G}$ coefficients. As with mortality, our results are most easily seen graphically, but we are also able to present them in tables given the smaller number of results. Standard errors are clustered on state.

\section{B. Results}

The first set of results shows the impact of recessions on access to health care. The dependent variable is an indicator for whether, during the past 12 months, the respondent did not see a doctor, when needed, due to cost. The coefficients are reported in Table 2 and shown graphically in

materially affected. Also, for the 2009 and 2010 surveys, there are observations in our sample for whom we have not yet observed all of the relevant unemployment rates for calculation of the three-year average unemployment rate in their age group. Again, we have re-estimated our regressions excluding the 2009 and 2010 survey years and find that the results are qualitatively similar. 
Figure 4, with diamond markers denoting any coefficients that are statistically significant at the 5 percent level. These results suggest that increases in the unemployment rate are associated with contemporaneous increases in the probability of missing a doctor's appointment due to cost, for recessions that occur before age 65, the age of Medicare entitlement. The magnitude of the contemporaneous effect ranges from a 0.181 to a 0.457 percentage point increase in the probability of a missed doctor's visit for a one percentage point increase in the unemployment rate. Interestingly, our results suggest that the elevated probability of a missed doctor visit associated with a recession persists for three to six years after the recession, suggesting that the impact of recessions on access to health care use may extend for a number of years. This long-term effect on access to care provides a plausible mechanism for recessions to have longer-term negative consequences for health. It is also worth noting that we see some evidence of increased access to care six to nine years after a recession, although of a smaller magnitude than the initial decrease. In the next set of results, we explore potential explanations for these patterns.

We next turn to measures of health insurance coverage as dependent variables. We use two measures of health insurance coverage: an indicator for having any health insurance coverage, and an indicator for having any private health insurance coverage. The health insurance questions in the CPS are intended to elicit information about insurance coverage in the prior year. However, survey respondents have a tendency to provide health insurance information about the survey year instead of the prior year (Swartz, 1986). Indeed, in our sample, reported Medicare coverage spikes from 16 percent among 64-year-old survey respondents to 83\% among 65-year-old survey respondents. This spike would not occur (or would be much smaller), if people were actually reporting their insurance status in the prior year. In light of this information, we treat the insurance data as if they apply to the survey year. Although this approach may introduce a bit of downward bias attributable to 
measurement error, the year-to-year serial correlation in unemployment likely dampens the magnitude of this problem. The coefficients are, again, shown graphically in figures, with diamond markers denoting any coefficients that are statistically significant at the 5 percent level.

Figure 5 shows coefficients in models where the dependent variable is an indicator for coverage by any form of insurance (Table 3 reports the same coefficients with corresponding standard errors). Not surprisingly, there is a large decline in the probability of any insurance coverage in periods of elevated unemployment for all age groups below the age of Medicare eligibility. The magnitude of the contemporaneous decline in the probability of insurance coverage ranges from 0.18 to 0.39 percentage points for a one percentage point increase in unemployment. These results are consistent with earlier findings on the contemporaneous effect of unemployment on health insurance coverage (Cawley and Simon, 2005; and Gruber and Levitt, 2002). ${ }^{16}$

Interestingly, Figure 5 also shows that the largest decline in insurance coverage, based on point estimates, is seen in the time period that is approximately 3 years after the recession. This lag is long enough that it is probably not attributable to serial correlation in unemployment rates, but it might reflect the fact that COBRA coverage mitigates the loss of health insurance in the first 18 months after a job loss. ${ }^{17}$ While the other coefficients are generally not statistically significant, the point estimates suggest that, for individuals who experience a labor market downturn at ages 53-55, it can take nearly a decade - until Medicare become available at age 65 - for insurance coverage to return to its pre-recession level. The fact that Medicare eligibility begins at age 65 ensures that those who experience recessions at ages 62 to 64 experience substantially shorter spells of uninsurance.

\footnotetext{
${ }^{16}$ The estimates by Gruber and Levitt (2002), like ours, are based on the CPS; they estimate effects that are slightly larger than ours (0.43 to 0.57 ), but this difference is likely attributable to the older population in our sample. In more recent work using the Survey of Income and Program Participation, Cawley et. al. (2011) estimate larger effects of the Great Recession on insurance coverage than those implied by earlier studies.

${ }^{17}$ COBRA coverage was introduced by legislation beginning in 1985 , so that it is available for most of our sample period.
} 
Recessions occurring after that age lead to no deficit in insurance coverage. These age patterns are quite consistent with the pattern of effects on financial access to care in the BRFSS and, therefore, may help to explain the finding that recessions are associated with a reduction in long-term survival when they coincide with an individual's late 50s and very early 60s but not if they occur at older ages.

Figure 6 focuses on private health insurance coverage (Table 4 shows the same coefficients and corresponding standard errors). ${ }^{18}$ For those under the age of 65 , private insurance is likely to be the individual's primary source of insurance; for those over the age of 65, private insurance is likely to be a supplemental insurance policy that covers copayments and deductibles for Medicare. About half of these supplemental insurance policies are purchased through former employers, and the other half are purchased individually on the Medigap market. Given the prevalence of private supplemental policies, it is not surprising that average private insurance coverage does not fall off very much at the age of Medicare eligibility; in our data, it falls from 78 percent at ages 62 to 64 to 71 percent at ages 65 to 67 . In Figure 6, we see that the decline in insurance coverage associated with higher unemployment is, not surprisingly, driven by declines in private health insurance coverage. As with the overall insurance coverage results, the largest impact on private health insurance coverage (based on point estimates) occurs with a lag of approximately three years, after COBRA coverage expires. The other notable result in this panel is the statistically significant increase in private health insurance coverage among those aged 68-70 associated with recessions that occurred when those individuals were in their mid-50s. One possible explanation for this result is that it is the result of increased labor market participation at older ages by those who experienced

\footnotetext{
${ }^{18}$ We have also examined the effect of recessions on public health insurance coverage. We find no statistically significant effect, which is not surprising given the eligibility rules for Medicare and Medicaid. We do not report these results in figures or tables.
} 
recessions in their 50s and may feel they need to work longer to make up for lost income and pension contributions. This finding may also explain the decreased financial barriers to health care that we found among those aged 68-73 associated with recessions that occurred when those individuals were in their mid-50s.

These results suggest the possibility of longer-term employment effects; we next examine labor market outcomes as a function of the unemployment rate at various ages. ${ }^{19}$ Our data set and empirical framework is identical to that for our insurance coverage regressions, but we now estimate linear probability models using an employment indicator as our key dependent variable. The results of this analysis are reported in Figure 7 and Table 5. All age groups, of course, experience a contemporaneous decline in employment when unemployment rates are high. Specifically, we find that a one percentage point increase in the unemployment rate is associated with a contemporaneous 0.3 to 0.5 percentage point decline in the probability of employment in our sample. The fact that there is not a one-for-one relationship between the unemployment rate and employment in our sample is likely related to the fact that older workers are typically less likely to lose their jobs during recessions than younger workers. ${ }^{20}$ The magnitude of the effect diminishes over time, but remains apparent in the data for 6 to 9 years.

Interestingly, we also observe a statistically significant increase in the probability of employment in an individual's late 60s and early 70s, lasting approximately 6 years, for those

\footnotetext{
${ }^{19}$ Although we are primarily interested in analyzing employment in order to put our other results into context, we acknowledge that retirement itself could have direct effects (either positive or negative) on physical and/or mental health. Unfortunately, it is difficult to estimate this empirically, since the potential for endogeneity is so great. For two recent examples from this literature, see Bound and Waidmann (2007) and Coe and Zamarro (2011).

${ }^{20}$ For example, Johnson and Butrica (2012) report that, in the most recent recession, during a period when the monthly employment rate for 25-to-34-year-olds was, on average, 9.4 percent, the unemployment rate for 50-to-61-year-olds was, on average, only 6.1 percent.
} 
cohorts that experienced recessions between the ages of 53 and $64 .^{21}$ This increase in employment after the age of normal retirement is shorter and less pronounced for those who experience recessions between the ages of 62 and $64 .^{22}$ This effect could suggest that some of those who experience a recession in their 50s need to remain in the labor force longer or return there later in life, to make up for lost incomes, pension accrual, or Social Security accrual. Those who experience a recession after they have reached the early entitlement age for Social Security, on the other hand, experience less loss of income and less loss of pension and Social Security accrual, and therefore do not increase their employment at older ages by as much. ${ }^{23}$ We have repeated this exercise using the natural log of total personal income in the CPS as the dependent variable and obtained patterns very similar to those described regarding employment, as one would expect.

\section{DISCUSSION}

Our results indicate that experiencing a recession in the years preceding retirement results in a short period in which mortality is lower, but a longer period in which mortality is higher, resulting in lower survival rates at older ages. A plausible mechanism for this longer-term finding is the long period of lower rates of employment, health insurance coverage, and access to health care that we find comes with exposure to an economic downturn in one's late 50s or early 60s. These effects

\footnotetext{
${ }^{21}$ This increase in employment appears to explain a portion of the increase in private health insurance coverage between the ages of 65 and 70 . When we use an indicator for having private health insurance and being employed as our dependent variable, we obtain coefficients that are similar to, but somewhat smaller than, those in Table 3.

${ }^{22}$ We have examined health insurance and employment outcomes by gender. We find some differences in point estimates, with generally larger health insurance effects for women and larger employment effects for men. However, these differences are not statistically significant.

${ }^{23}$ It is worth noting that these effects are generally at least an order of magnitude larger than the effects on survival probabilities, so these results are not explained by selection bias due to the deaths of the individuals who were least likely to remain in the labor force at older ages. Working longer in response to experiencing a recession in the late 50s and very early 60s could have a positive or negative potential impact on long-term mortality. If it were negative, this could be a potential mechanism driving our mortality effects. We are unaware of any literature that directly addresses the link between labor market longevity and longer-term survival probabilities.
} 
could go on for several years for affected workers and appear to be ameliorated by eligibility for Social Security and Medicare at ages 62 and 65, respectively.

One useful exercise that would help support the plausibility of these findings is a comparison of the relative magnitudes of their effects. We begin with the employment effects, which should be the largest in magnitude. As described earlier, a one percentage point increase in the unemployment rate at, say, ages 56-58 reduces the likelihood of any employment at those ages by 0.5 percentage points. The less than point-for-point impact makes sense because older workers do not suffer as much job loss as the average worker when a recession hits; furthermore, since the relevant outcome is any employment, workers whose unemployment spells are short would not be captured here. This effect does not dissipate by ages 59-61 but falls by about half at ages 62-64 (after Social Security becomes available) and then falls again to roughly zero by 65-67 (after the Social Security normal retirement age passes). We believe these results are plausible and suggestive of long-term employment losses for many older workers who experience a job loss.

The estimated effects on health insurance coverage suggest that the same one percentage point increase in the unemployment rate at ages 56-58 reduces private health insurance coverage by around 0.25 percentage points from those ages through ages 62-64 (although the effect is only statistically significant at 59-61, suggesting the power of this analysis is somewhat limited). This indicates that roughly half of those with long-term employment losses also lose access to private health insurance. Spousal coverage is likely to account for those who do not, as well as COBRA coverage in the short run; there is also no loss in insurance for those job losers who were uninsured even when working. The impact on any health insurance coverage could also be mitigated if unemployed older workers apply for and receive Social Security disability insurance (cf. Autor and Duggan, 2003), although Medicare coverage is only available starting two years after the onset of 
the disability. The magnitude of the estimated effect on reporting missing a doctor visit due to cost is similar to the magnitude of the effect on insurance coverage, which would indicate that almost all of those who lose health insurance coverage experience financial barriers to care. This seems plausible, especially for an age group where doctor visits are quite common.

In terms of survival probabilities, we find that a one percentage point increase in the unemployment rate at, say, age 58 reduces the likelihood of surviving through age 79 by 0.045 percentage points. This means that if the entire impact on survival is generated from those initial workers who suffered long-term unemployment resulting from a recession, an additional one in ten of those workers would not survive to age 79 as a result of the labor market downturn. An alternative way to interpret these numbers is to estimate the impact on life expectancy assuming that all of the survival effect was transmitted through employment reductions. These calculations suggest that a worker who lost their job at age 58 as a result of a recession could be expected to live three fewer years (19 years instead of 22) as a result. It is important to interpret these numbers with some caution. First, lost employment does not need to be the only mechanism for such an effect, as Miller, et al. (2009) and Stevens, et al. (2011) indicate, which would result in overstated effects on job losers. Second, standard errors are associated with each of these estimates, suggesting that some confidence interval exists around these estimates. Nevertheless, incorporating these caveats, we believe that these magnitudes are plausible.

Another critical element in interpreting our results is the relationship between our findings and those of past analyses that have examined similar questions. As we described earlier, there are a number of relevant previous studies and their findings are not obviously consistent with each other. Ruhm (2000) found a general reduction in contemporaneous mortality associated with an economic downturn. Sullivan and von Wachter (2009) find that job displacement among long-tenured men 
increased mortality in the short- and long-term, particularly for those at prime working age. Miller, et al. (2009) show that higher unemployment rates generate reduced contemporaneous mortality, particularly for elderly individuals. We find negative short-term mortality effects that are consistent with Miller, et al. (2009) for workers in their late 50s and very early 60s, but then we find reduced longevity for these workers. Taken at face value, virtually all of these results appear to contradict each other.

These conflicts have been noted by the authors of previous studies and several explanations have been offered. Sullivan and von Wachter (2009) make a distinction between the average worker who loses his or her job in a recession and the high-tenure displaced workers that they study, who presumably suffer a considerably more severe economic shock resulting from their unemployment. In their view, the differential effects between the two groups (the former being considerably larger) are reasonable, so there is no conflict with Ruhm (2000). Miller, et al. (2009) argue that the differences in their findings as compared to those of Ruhm (2000) result from the fact that health improvements observed during a recession are not the result of changes in own labor force status, but are attributable to external factors, which they go on to explore in more detail in Stevens, et al. (2011).

Our own evidence builds on some of these arguments, but other discrepancies between our findings and the more recent entries into this literature also need to be reconciled. In comparing our results with those of Miller, et al./Stevens, et al., the main distinction is in terms of interpretation; they argue that the main effect of a recession is external to the employment relationship. That may be true for the short-term impact and our short-term results are very similar to their findings. On the other hand, we believe that our findings are consistent with reduced employment, health insurance coverage, and health care access plausibly explaining a significant portion of the long-term negative 
health impact. Since their analysis never focuses on these long-term effects, there is no direct conflict in our interpretations.

Our primary result - that recessions have negative long-term effects on survival for those approaching retirement - is also mainly consistent with the key findings of Sullivan and von Wachter (2009). One place where the papers may appear to diverge is in the relative effect of unemployment at different ages. We find that unemployment shocks at ages 57 to 61 have the biggest long-term effect on survival, while shocks at earlier (ages 55 to 56) or later (ages 62 to 65) ages have no significant long-term effect. Sullivan and von Wachter find that shocks occurring at younger ages (before age 45 or between ages 45 and 54) have a bigger effect than those at older ages (age 55 and above). Yet since we do not study the effect of shocks at younger ages, the two sets of results are not directly comparable; Sullivan and von Wachter do not provide results by exact age that could be compared against our results. A second point of divergence between the two papers is that we find positive effects of unemployment shocks on survival in the short run, while they find negative effects in both the short- and long-term. As already discussed, the effect of unemployment on an average worker may be different from that on a high-tenure worker. For example, employment and income losses may be less severe for average workers. As a result, average displaced workers may be spared the negative short-term mortality effects that plague those displaced from long-tenured positions, but both groups appear to suffer negative long-run health consequences.

Overall, our findings suggest that experiencing a recession in one's late 50s or early 60s is bad for health in the long run. Interestingly, we find that unemployment shocks at or after age 62 have no long-term negative health effects. The availability of Social Security at age 62 and Medicare at age 65 may play an important role in this finding. These programs serve as a buffer 
against the income and health insurance losses that often accompany unemployment. Indeed, we find that unemployment shocks trigger lengthy reductions in employment and income for older workers; Social Security starts filling in the income gap at age 62. These shocks also trigger lengthy reductions in insurance coverage and increased difficulty in accessing health care; these effects disappear once individuals reach age 65 when Medicare begins. ${ }^{24}$ As policy makers contemplate possible changes to Social Security and Medicare to restore them to stronger financial footing, such as raising the age of eligibility for these programs, it will be important to develop a better understanding of the role that these programs may play in mitigating the negative effects of an unemployment shock.

\footnotetext{
${ }^{24}$ The fact that the impact on mortality ends at age 62 may simply mean that gaps in insurance coverage of a year or two may not substantively alter subsequent mortality.
} 


\section{REFERENCES}

Aguiar, Mark, Erik Hurst, and Loukas Karabarbounis (2011). “Time Use During Recessions,” NBER Working Paper 17259.

Asgeirsdottir, Tinna, Hope Corman, Kelly Noonan, Porhilder Olafsdottir, Nancy Reichman (2011). "Are Recessions Good for Your Health Behaviors? Impacts of the Economic Crisis in Iceland," NBER Working Paper 18233.

Autor, David and Mark Duggan (2003). "The Rise in the Disability Rolls and the Decline in Unemployment." Quarterly Journal of Economics, 118(1): 157 - 206.

Bound, John and Timothy Waidmann (2007). "Estimating the Health Effects of Retirement," Michigan Retirement Research Center Working Paper WP 2007-168.

Cawley, John, Asako Moriya, and Kosali I. Simon (2011). “The Impact of the Macroeconomy on Health Insurance Coverage: Evidence from the Great Recession,” NBER Working Paper 17600.

Cawley, John and Kosali I. Simon (2005). "Health Insurance Coverage and the Macroeconomy," Journal of Health Economics, 24(2): 299-315.

Coe, Norma and Gema Zamarro (2011). “Retirement Effects on Health in Europe,” Journal of Health Economics 30(1):77-86.

Coile, Courtney C. (2004). "Health Shocks and Couples' Labor Supply Decisions,” NBER Working Paper 10810, October.

Coile, Courtney C. and Phillip B. Levine (2010). Reconsidering Retirement: How Losses and Layoffs Affect Older Workers. Washington, DC: Brookings Institution Press.

Coile, Courtney C. and Phillip B. Levine (2011a). "Recessions, Retirement, and Social Security," American Economic Review Papers and Proceedings, 101(3): 23-28.

Coile, Courtney C. and Phillip B. Levine (2011b). "Recessions, Reeling Markets, and Retiree WellBeing,” The B.E. Journal of Economic Analysis \& Policy (Contributions): 11(1): Article 22.

Government Accountability Office (2012). Unemployed Older Workers: Many Experience Challenges Regaining Employment and Face Reduced Retirement Security. Washington, DC: U.S. Government Accountability Office.

Gruber, Jonathan and Larry Levitt (2002). “Rising Unemployment and the Uninsured,” Kaiser Family Foundation Publication \#6011.

Johnson, Richard W. and Barbara Butrica (2012). “Age Disparities in Unemployment and Reemployment During the Great Recession and Recovery," Urban Intitute Issue Brief \#3, Downloaded from http://www.urban.org/publications/412574.html on May 15, 2012. 
Lahey, Joanna N. (2008). "Age, Women, and Hiring: An Experimental Study." Journal of Human Resources 43(1): 30-56.

Miller, Douglas L., Marianne E. Page, Ann Huff Stevens, and Mateusz Filipski (2009). "Why are Recessions Good for Your Health?” American Economic Review: Papers \& Proceedings 99(2): 122127.

Ruhm, Christopher J. (2000). “Are Recessions Good for Your Health?” Quarterly Journal of Economics 115(2): 617-650.

Ruhm, Christopher J. (2003). “Good times Make You Sick,” Journal of Health Economics 22(4): 637-658.

Ruhm, Christopher J. (2005). "Healthy Living in Hard Times," Journal of Health Economics 24(2): 341-363.

Snyder, Stephen E. and William N. Evans (2006). "The Effect Of Income On Mortality: Evidence From The Social Security Notch," Review of Economics and Statistics, 88(3): 482-495.

Stevens, Ann Huff, Douglas L. Miller, Marianne E. Page, Mateusz Filipski (2011). "The Best of Times, The Worst of Times: Understanding Pro-cyclical Mortality,” NBER Working Paper \#17657.

Sullivan, Daniel and von Wachter, Till (2009). “Job Displacement and Mortality: An Analysis Using Administrative Data,” Quarterly Journal of Economics 124(3): 1265-1306.

Swartz, Katherine (1986). "Interpreting the Estimates from Four National Surveys of the Number of People without Health Insurance,” Journal of Economic and Social Measurement 14(3): 233-42.

U.S. Department of Labor (various years). Manpower Reports of the President. Washington, DC: U.S. Department of Labor. 
Table 1: Impact of Changes in Structure of Data on the Relationship between Contemporaneous Unemployment Rates on Mortality (coefficients and standard errors multiplied by 100)

\begin{tabular}{|c|c|c|c|c|c|c|c|c|}
\hline & $\begin{array}{c}\text { Mean } \\
\text { Mortality Rate } \\
(1)\end{array}$ & $\begin{array}{c}\text { Mean } \\
\text { Mortality Rate } \\
(2)\end{array}$ & $\begin{array}{l}\text { Stevens, et al. } \\
\text { (2011) } \\
\text { (3) }\end{array}$ & $\begin{array}{c}\text { Replication } \\
(4)\end{array}$ & $\begin{array}{c}\text { Drop } \\
\text { Explanatory } \\
\text { Variables } \\
\text { (5) }\end{array}$ & $\begin{array}{l}\text { Expand to } \\
\text { All Years } \\
(6)\end{array}$ & $\begin{array}{l}\text { Focus on } \\
\text { Birth } \\
\text { Cohorts } \\
(7)\end{array}$ & $\begin{array}{c}\text { Convert mortality } \\
\text { rate from } \\
\text { logs to levels } \\
\text { (8) }\end{array}$ \\
\hline $\begin{array}{l}\text { Survey Years/ } \\
\text { Birth Cohorts: }\end{array}$ & $\begin{array}{c}\text { 1969-2008/ } \\
\text { variable }\end{array}$ & $\begin{array}{c}\text { Variable/ } \\
\text { 1910-1929 } \\
\end{array}$ & $\begin{array}{c}\text { 1978-2006/ } \\
\text { variable }\end{array}$ & $\begin{array}{c}\text { 1978-2006/ } \\
\text { variable }\end{array}$ & $\begin{array}{c}\text { 1978-2006/ } \\
\text { variable }\end{array}$ & $\begin{array}{c}\text { 1969-2008/ } \\
\text { variable }\end{array}$ & $\begin{array}{c}\text { Variable/ } \\
1910-1929 \\
\end{array}$ & $\begin{array}{c}\text { Variable/ } \\
\text { 1910-1929 }\end{array}$ \\
\hline Age 55 & $0.80 \%$ & $0.98 \%$ & $\begin{array}{l}-0.019 \\
(0.236)\end{array}$ & $\begin{array}{l}-0.048 \\
(0.240)\end{array}$ & $\begin{array}{l}-0.020 \\
(0.259)\end{array}$ & $\begin{array}{l}-0.237 \\
(0.187)\end{array}$ & $\begin{array}{l}-0.246 \\
(0.223)\end{array}$ & $\begin{array}{l}-0.0025 \\
(0.0021)\end{array}$ \\
\hline Age 60 & $1.24 \%$ & $1.45 \%$ & $\begin{array}{c}0.148 \\
(0.168)\end{array}$ & $\begin{array}{c}0.128 \\
(0.166)\end{array}$ & $\begin{array}{c}0.079 \\
(0.172)\end{array}$ & $\begin{array}{l}-0.013 \\
(0.154)\end{array}$ & $\begin{array}{c}0.039 \\
(0.145)\end{array}$ & $\begin{array}{l}-0.0013 \\
(0.0020)\end{array}$ \\
\hline Age 65 & $1.88 \%$ & $1.99 \%$ & $\begin{array}{l}-0.189 \\
(0.169)\end{array}$ & $\begin{array}{l}-0.162 \\
(0.170)\end{array}$ & $\begin{array}{l}-0.255 \\
(0.159)\end{array}$ & $\begin{array}{l}-0.417 \\
(0.116)\end{array}$ & $\begin{array}{l}-0.324 \\
(0.140)\end{array}$ & $\begin{array}{l}-0.0062 \\
(0.0028)\end{array}$ \\
\hline Age 70 & $2.80 \%$ & $2.78 \%$ & $\begin{array}{l}-0.599 \\
(0.143)\end{array}$ & $\begin{array}{l}-0.614 \\
(0.146)\end{array}$ & $\begin{array}{l}-0.572 \\
(0.205)\end{array}$ & $\begin{array}{l}-0.670 \\
(0.147)\end{array}$ & $\begin{array}{l}-0.757 \\
(0.244)\end{array}$ & $\begin{array}{l}-0.0221 \\
(0.0067)\end{array}$ \\
\hline Age 75 & $4.21 \%$ & $3.96 \%$ & $\begin{array}{c}-0.300 \\
(0.152)\end{array}$ & $\begin{array}{c}-0.308 \\
(0.152)\end{array}$ & $\begin{array}{c}-0.148 \\
(0.110)\end{array}$ & $\begin{array}{c}-0.229 \\
(0.105)\end{array}$ & $\begin{array}{c}0.034 \\
(0.171)\end{array}$ & $\begin{array}{c}-0.0036 \\
(0.0067)\end{array}$ \\
\hline
\end{tabular}

Notes: Every cell in the table represents the coefficient on the unemployment rate in a model where the dependent variable is measured in natural logs (except where noted) and that also includes year or birth cohort fixed effects, state fixed effects, and statespecific linear trends. In cohort models, ages 55 through 58 uses all available cohorts, which do not go as far back as 1910 (i.e. for those age 55, the 1914 birth cohort is the first available). Regressions weighted by state/year/age population. 
Table 2: Impact of Unemployment Rates at Specific Age Groups on Skipping Doctor Visits Due to Cost in the Past 12 Months at Different Ages

\begin{tabular}{|c|c|c|c|c|c|c|c|c|c|}
\hline \multirow{2}{*}{$\begin{array}{c}\text { Unemp. Rate } \\
\text { at Age }\end{array}$} & \multicolumn{9}{|c|}{ Any Insurance at Age: } \\
\hline & $53-55$ & $56-58$ & $59-61$ & $62-64$ & $65-67$ & $68-70$ & $71-73$ & 74-76 & 77-79 \\
\hline $53-55$ & $\begin{array}{l}0.457^{* *} \\
(0.086)\end{array}$ & $\begin{array}{l}0.328^{* *} \\
(0.134)\end{array}$ & $\begin{array}{l}-0.167 \\
(0.148)\end{array}$ & $\begin{array}{l}-0.238^{* *} \\
(0.099)\end{array}$ & $\begin{array}{l}-0.183^{*} \\
(0.099)\end{array}$ & $\begin{array}{l}-0.105 \\
(0.063)\end{array}$ & $\begin{array}{c}0.108^{*} \\
(0.062)\end{array}$ & $\begin{array}{l}-0.018 \\
(0.056)\end{array}$ & $\begin{array}{c}-0.051 \\
(0.061)\end{array}$ \\
\hline $56-58$ & & $\begin{array}{c}0.196 \\
(0.124)\end{array}$ & $\begin{array}{l}0.225^{* *} \\
(0.102)\end{array}$ & $\begin{array}{c}-0.003 \\
(0.135)\end{array}$ & $\begin{array}{c}-0.041 \\
(0.102)\end{array}$ & $\begin{array}{l}-0.158^{*} \\
(0.086)\end{array}$ & $\begin{array}{c}-0.041 \\
(0.088)\end{array}$ & $\begin{array}{c}0.117 \\
(0.081)\end{array}$ & $\begin{array}{c}-0.051 \\
(0.070)\end{array}$ \\
\hline $59-61$ & & & $\begin{array}{l}0.364^{* *} \\
(0.100)\end{array}$ & $\begin{array}{c}0.197^{*} \\
(0.112)\end{array}$ & $\begin{array}{l}0.240^{* *} \\
(0.101)\end{array}$ & $\begin{array}{l}-0.175^{*} \\
(0.100)\end{array}$ & $\begin{array}{l}-0.202^{* *} \\
(0.078)\end{array}$ & $\begin{array}{c}0.050 \\
(0.075)\end{array}$ & $\begin{array}{c}-0.023 \\
(0.068)\end{array}$ \\
\hline $62-64$ & & & & $\begin{array}{l}0.181^{* *} \\
(0.081)\end{array}$ & $\begin{array}{c}0.061 \\
(0.095)\end{array}$ & $\begin{array}{c}0.060 \\
(0.094)\end{array}$ & $\begin{array}{l}-0.011 \\
(0.093)\end{array}$ & $\begin{array}{c}-0.053 \\
(0.113)\end{array}$ & $\begin{array}{l}-0.026 \\
(0.073)\end{array}$ \\
\hline $65-67$ & & & & & $\begin{array}{c}0.126 \\
(0.081) \\
\end{array}$ & $\begin{array}{l}-0.035 \\
(0.094) \\
\end{array}$ & $\begin{array}{c}0.058 \\
(0.110) \\
\end{array}$ & $\begin{array}{c}-0.026 \\
(0.111) \\
\end{array}$ & $\begin{array}{l}-0.020 \\
(0.081) \\
\end{array}$ \\
\hline $\mathrm{N}$ & 210,803 & 227,861 & 217,473 & 205,682 & 200,904 & 178,795 & 159,516 & 143,812 & 124,055 \\
\hline $\begin{array}{c}\text { Mean of } \\
\text { Dependent } \\
\text { Variable }\end{array}$ & 0.131 & 0.119 & 0.108 & 0.100 & 0.064 & 0.047 & 0.043 & 0.040 & 0.037 \\
\hline
\end{tabular}

Notes: Every cell in the table represents the coefficient on the unemployment rate in a linear probability model that also includes year fixed effects, state fixed effects, and state-specific linear trends. Coefficients and standard errors are multiplied by 100 . As noted in the text, the number of observations varies slightly in some specifications. The number of observations here is the most common number of observations. A double (single) asterisk represents a coefficient that is significant at the 5 (10) percent level. 
Table 3: Impact of Unemployment Rates at Specific Age Groups on Any Health Insurance Coverage at Different Ages

\begin{tabular}{|c|c|c|c|c|c|c|c|c|c|}
\hline \multirow{2}{*}{$\begin{array}{c}\text { Unemp. Rate } \\
\text { at Age }\end{array}$} & \multicolumn{9}{|c|}{ Any Insurance at Age: } \\
\hline & $53-55$ & $56-58$ & $59-61$ & $62-64$ & $65-67$ & $68-70$ & $71-73$ & $74-76$ & $77-79$ \\
\hline $53-55$ & $\begin{array}{l}-0.213^{* *} \\
(0.108)\end{array}$ & $\begin{array}{l}-0.352^{* *} \\
(0.127)\end{array}$ & $\begin{array}{l}-0.128 \\
(0.119)\end{array}$ & $\begin{array}{c}-0.032 \\
(0.151)\end{array}$ & $\begin{array}{c}0.05 \\
(0.035)\end{array}$ & $\begin{array}{c}-0.02 \\
(0.041)\end{array}$ & $\begin{array}{c}-0.008 \\
(0.045)\end{array}$ & $\begin{array}{c}-0.019 \\
(0.043)\end{array}$ & $\begin{array}{c}-0.008 \\
(0.027)\end{array}$ \\
\hline $56-58$ & & $\begin{array}{l}-0.208 \\
(0.134)\end{array}$ & $\begin{array}{l}-0.121 \\
(0.122)\end{array}$ & $\begin{array}{l}-0.068 \\
(0.156)\end{array}$ & $\begin{array}{l}-0.009 \\
(0.045)\end{array}$ & $\begin{array}{c}0.019 \\
(0.048)\end{array}$ & $\begin{array}{c}0.01 \\
(0.039)\end{array}$ & $\begin{array}{c}0.028 \\
(0.035)\end{array}$ & $\begin{array}{c}-0.074^{* *} \\
(0.028)\end{array}$ \\
\hline $59-61$ & & & $\begin{array}{l}-0.176^{*} \\
(0.104)\end{array}$ & $\begin{array}{c}-0.386^{* *} \\
(0.135)\end{array}$ & $\begin{array}{l}-0.029 \\
(0.050)\end{array}$ & $\begin{array}{c}0.005 \\
(0.041)\end{array}$ & $\begin{array}{l}-0.037 \\
(0.024)\end{array}$ & $\begin{array}{c}0.002 \\
(0.036)\end{array}$ & $\begin{array}{c}-0.054^{* *} \\
(0.022)\end{array}$ \\
\hline $62-64$ & & & & $\begin{array}{l}-0.393^{* *} \\
(0.145)\end{array}$ & $\begin{array}{c}-0.01 \\
(0.065)\end{array}$ & $\begin{array}{l}-0.029 \\
(0.055)\end{array}$ & $\begin{array}{c}0.024 \\
(0.032)\end{array}$ & $\begin{array}{l}-0.006 \\
(0.043)\end{array}$ & $\begin{array}{l}-0.014 \\
(0.033)\end{array}$ \\
\hline $65-67$ & & & & & $\begin{array}{c}0.082 \\
(0.075) \\
\end{array}$ & $\begin{array}{c}0.041 \\
(0.035) \\
\end{array}$ & $\begin{array}{c}0.025 \\
(0.039) \\
\end{array}$ & $\begin{array}{c}-0.016 \\
(0.038) \\
\end{array}$ & $\begin{array}{c}-0.003 \\
(0.033) \\
\end{array}$ \\
\hline $\mathrm{N}$ & 136,133 & 132,182 & 117,873 & 102,652 & 93,036 & 81,333 & 70,886 & 61,633 & 51,637 \\
\hline $\begin{array}{c}\text { Mean of } \\
\text { Dependent } \\
\text { Variable }\end{array}$ & 0.88 & 0.88 & 0.88 & 0.88 & 0.98 & 0.99 & 0.99 & 0.99 & 0.99 \\
\hline
\end{tabular}


Table 4: Impact of Unemployment Rates at Specific Age Groups on Private Health Insurance Coverage at Different Ages

\begin{tabular}{|c|c|c|c|c|c|c|c|c|c|}
\hline \multirow[b]{2}{*}{$\begin{array}{l}\text { Unemp. Rate } \\
\text { at Age }\end{array}$} & \multicolumn{9}{|c|}{ Any Insurance at Age: } \\
\hline & $53-55$ & $56-58$ & 59-61 & $62-64$ & $65-67$ & $68-70$ & $71-73$ & $74-76$ & $77-79$ \\
\hline 53-55 & $\begin{array}{l}-0.087 \\
(0.117)\end{array}$ & $\begin{array}{l}-0.335^{* *} \\
(0.157)\end{array}$ & $\begin{array}{c}-0.128 \\
(0.165)\end{array}$ & $\begin{array}{c}-0.149 \\
(0.200)\end{array}$ & $\begin{array}{c}0.416 \\
(0.284)\end{array}$ & $\begin{array}{l}0.470^{* *} \\
(0.188)\end{array}$ & $\begin{array}{c}0.309 \\
(0.269)\end{array}$ & $\begin{array}{l}-0.120 \\
(0.247)\end{array}$ & $\begin{array}{l}-0.349 \\
(0.217)\end{array}$ \\
\hline $56-58$ & & $\begin{array}{l}-0.209 \\
(0.142)\end{array}$ & $\begin{array}{c}-0.323^{* *} \\
(0.150)\end{array}$ & $\begin{array}{l}-0.235 \\
(0.191)\end{array}$ & $\begin{array}{c}0.314 \\
(0.237)\end{array}$ & $\begin{array}{l}0.646^{* *} \\
(0.188)\end{array}$ & $\begin{array}{c}0.420 \\
(0.257)\end{array}$ & $\begin{array}{c}0.035 \\
(0.287)\end{array}$ & $\begin{array}{c}-0.479^{* *} \\
(0.198)\end{array}$ \\
\hline $59-61$ & & & $\begin{array}{c}-0.302^{* *} \\
(0.135)\end{array}$ & $\begin{array}{c}-0.368^{* *} \\
(0.154)\end{array}$ & $\begin{array}{c}0.057 \\
(0.216)\end{array}$ & $\begin{array}{c}0.008 \\
(0.214)\end{array}$ & $\begin{array}{c}0.105 \\
(0.297)\end{array}$ & $\begin{array}{l}-0.112 \\
(0.322)\end{array}$ & $\begin{array}{c}0.134 \\
(0.272)\end{array}$ \\
\hline $62-64$ & & & & $\begin{array}{l}-0.311^{*} \\
(0.164)\end{array}$ & $\begin{array}{l}-0.222 \\
(0.237)\end{array}$ & $\begin{array}{c}-0.510^{* *} \\
(0.188)\end{array}$ & $\begin{array}{c}0.054 \\
(0.250)\end{array}$ & $\begin{array}{c}0.110 \\
(0.267)\end{array}$ & $\begin{array}{c}0.418^{*} \\
(0.230)\end{array}$ \\
\hline $65-67$ & & & & & $\begin{array}{c}-0.156 \\
(0.307) \\
\end{array}$ & $\begin{array}{c}-0.334 \\
(0.273) \\
\end{array}$ & $\begin{array}{l}-0.241 \\
(0.295) \\
\end{array}$ & $\begin{array}{c}0.221 \\
(0.205) \\
\end{array}$ & $\begin{array}{c}0.325 \\
(0.216) \\
\end{array}$ \\
\hline $\mathrm{N}$ & 136,133 & 131,454 & 117,058 & 101,731 & 90,587 & 78,810 & 68,747 & 59,686 & 50,082 \\
\hline $\begin{array}{l}\text { Mean of } \\
\text { Dependent } \\
\text { Variable }\end{array}$ & 0.82 & 0.82 & 0.81 & 0.79 & 0.71 & 0.70 & 0.68 & 0.67 & 0.66 \\
\hline
\end{tabular}


Table 5: Impact of Unemployment Rates at Specific Age Groups on Employment at Different Ages

\begin{tabular}{|c|c|c|c|c|c|c|c|c|c|}
\hline \multirow{2}{*}{$\begin{array}{c}\text { Unemp. Rate } \\
\text { at Age }\end{array}$} & \multicolumn{9}{|c|}{ Any Employment at Age: } \\
\hline & $53-55$ & $56-58$ & $59-61$ & $62-64$ & $65-67$ & $68-70$ & $71-73$ & $74-76$ & $77-79$ \\
\hline 53-55 & $\begin{array}{l}-0.550^{* *} \\
(0.104)\end{array}$ & $\begin{array}{l}-0.242^{*} \\
(0.135)\end{array}$ & $\begin{array}{l}-0.207 \\
(0.209)\end{array}$ & $\begin{array}{c}0.246 \\
(0.149)\end{array}$ & $\begin{array}{c}0.157 \\
(0.155)\end{array}$ & $\begin{array}{l}0.268^{* *} \\
(0.122)\end{array}$ & $\begin{array}{l}0.546^{* *} \\
(0.149)\end{array}$ & $\begin{array}{c}-0.030 \\
(0.124)\end{array}$ & $\begin{array}{r}-0.080 \\
(0.120)\end{array}$ \\
\hline $56-58$ & & $\begin{array}{l}-0.500^{* *} \\
(0.139)\end{array}$ & $\begin{array}{l}-0.614^{* *} \\
(0.189)\end{array}$ & $\begin{array}{l}-0.256^{*} \\
(0.148)\end{array}$ & $\begin{array}{l}-0.035 \\
(0.149)\end{array}$ & $\begin{array}{l}0.373^{* *} \\
(0.112)\end{array}$ & $\begin{array}{l}0.503^{* *} \\
(0.140)\end{array}$ & $\begin{array}{c}0.087 \\
(0.128)\end{array}$ & $\begin{array}{c}0.057 \\
(0.103)\end{array}$ \\
\hline $59-61$ & & & $\begin{array}{c}-0.258 \\
(0.163)\end{array}$ & $\begin{array}{l}-0.333^{*} \\
(0.169)\end{array}$ & $\begin{array}{c}-0.297^{* *} \\
(0.141)\end{array}$ & $\begin{array}{c}0.073 \\
(0.129)\end{array}$ & $\begin{array}{c}0.227^{*} \\
(0.116)\end{array}$ & $\begin{array}{c}0.185^{*} \\
(0.108)\end{array}$ & $\begin{array}{c}-0.099 \\
(0.104)\end{array}$ \\
\hline $62-64$ & & & & $\begin{array}{c}-0.541^{* *} \\
(0.181)\end{array}$ & $\begin{array}{l}-0.522^{* *} \\
(0.147)\end{array}$ & $\begin{array}{c}-0.313^{* *} \\
(0.117)\end{array}$ & $\begin{array}{l}-0.003 \\
(0.140)\end{array}$ & $\begin{array}{l}0.182^{* *} \\
(0.068)\end{array}$ & $\begin{array}{c}0.055 \\
(0.111)\end{array}$ \\
\hline $65-67$ & & & & & $\begin{array}{c}-0.148 \\
(0.168) \\
\end{array}$ & $\begin{array}{l}-0.314^{* *} \\
(0.151)\end{array}$ & $\begin{array}{l}-0.275^{* *} \\
(0.120)\end{array}$ & $\begin{array}{c}-0.058 \\
(0.125) \\
\end{array}$ & $\begin{array}{c}0.166 \\
(0.100) \\
\end{array}$ \\
\hline $\mathrm{N}$ & 153,389 & 153,624 & 140,041 & 126,213 & 117,267 & 104,256 & 91,875 & 79,506 & 65,348 \\
\hline $\begin{array}{c}\text { Mean of } \\
\text { Dependent } \\
\text { Variable }\end{array}$ & 0.73 & 0.66 & 0.57 & 0.39 & 0.25 & 0.18 & 0.13 & 0.09 & 0.07 \\
\hline
\end{tabular}

Notes: Every cell in the table represents the coefficient on the unemployment rate in a linear probability model that also includes year fixed effects, state fixed effects, and state-specific linear trends. Coefficients and standard errors are multiplied by 100 . As noted in the text, the number of observations varies slightly in some specifications. The number of observations here is the most common number of observations. A double (single) asterisk represents a coefficient that is significant at the 5 (10) percent level. 
Figure 1: Survival Rates from Age 55, by Birth Cohort

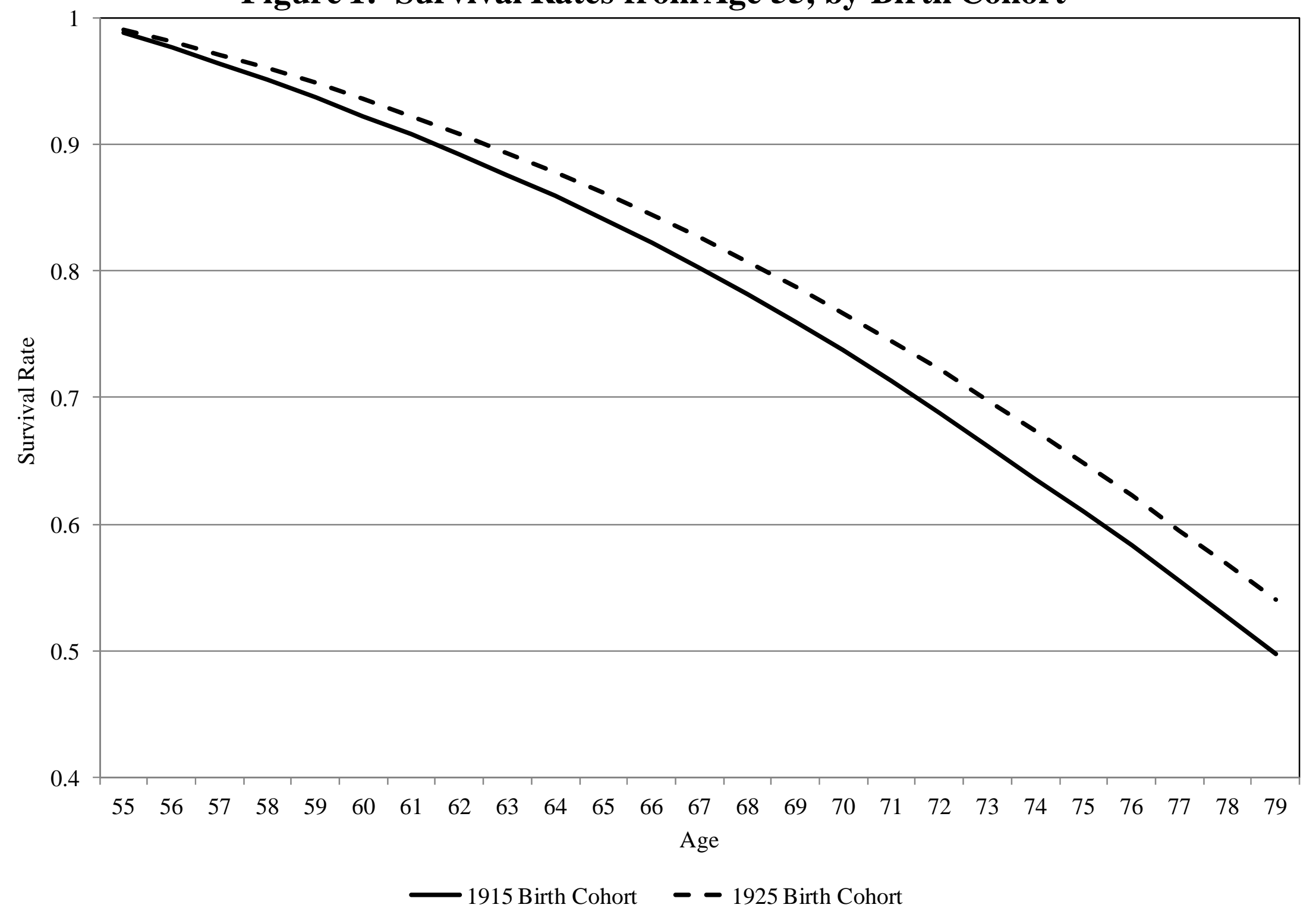


Figure 2: Impact of Unemployment Rate

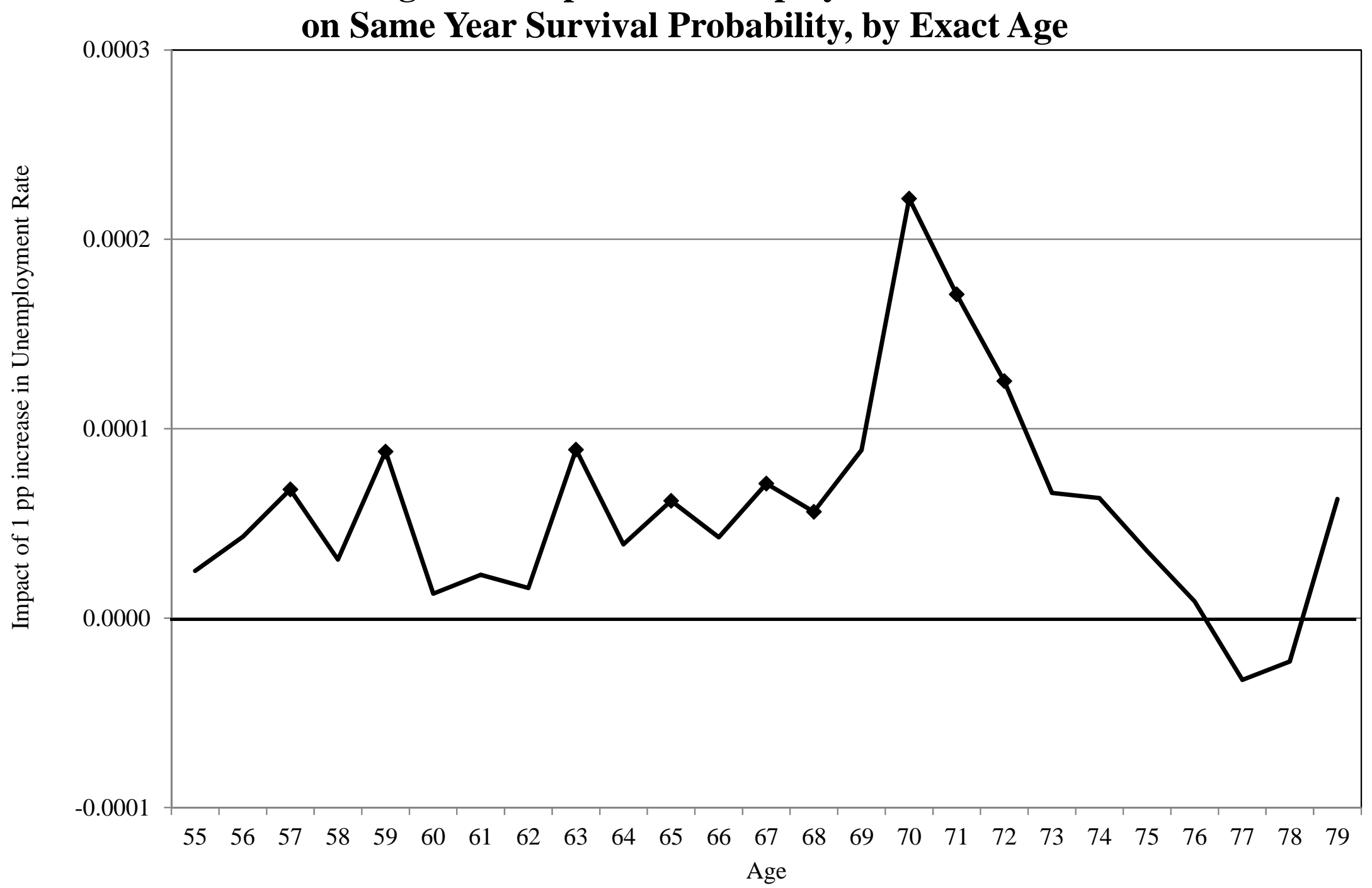

note: diamonds represent statistically significant (at the $5 \%$ level) estimates. 
Figure 3: Impact of Unemployment Rate at Various Ages

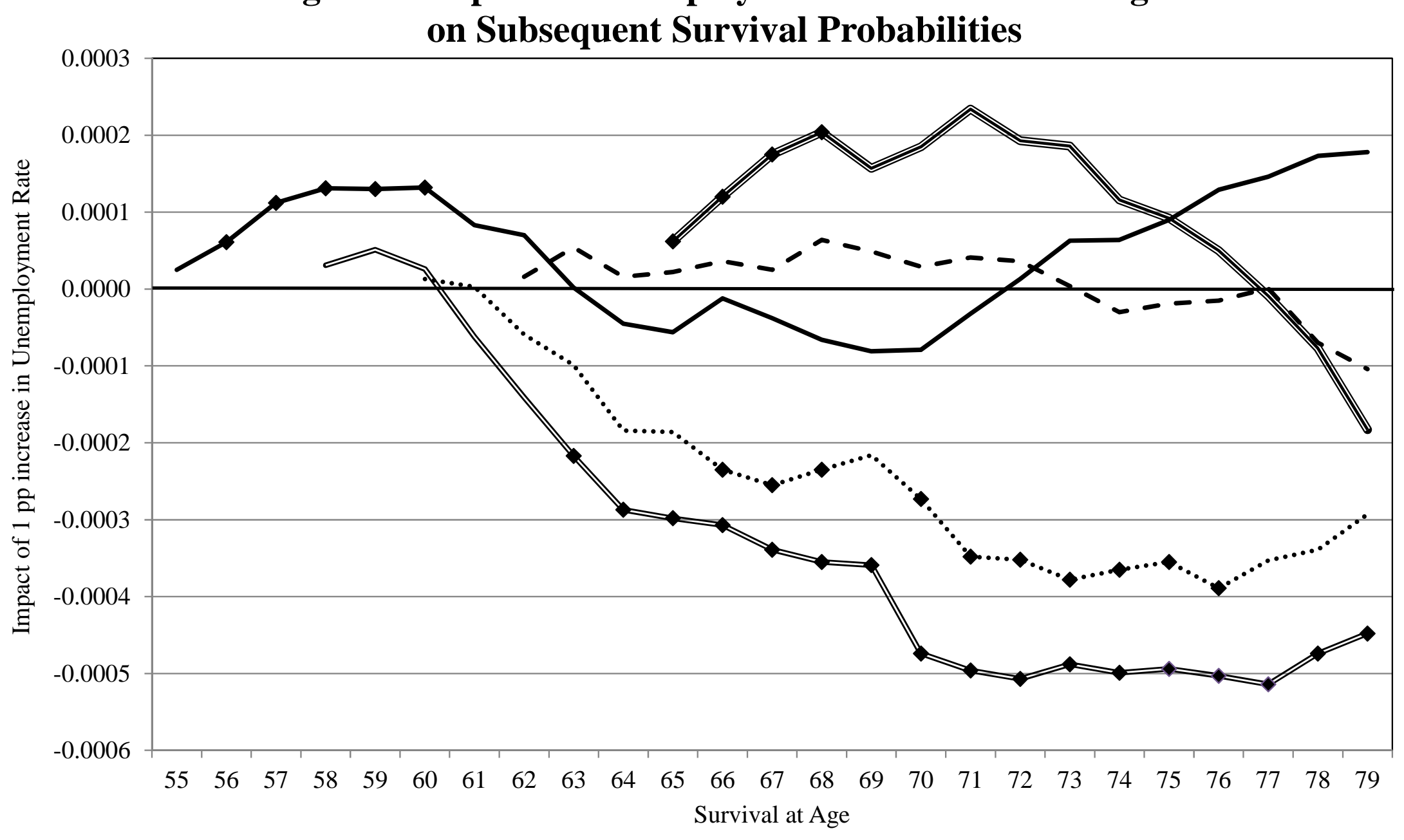

Unemployment Rate Measured at Age:

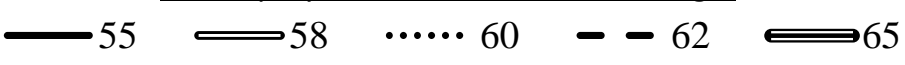

note: diamonds represent statistically significant (at the $5 \%$ level) estimates. 
Figure 4: Impact of Unemployment Rate at Various Ages on the Probability of Avoiding a Doctor's Visit Because of Cost

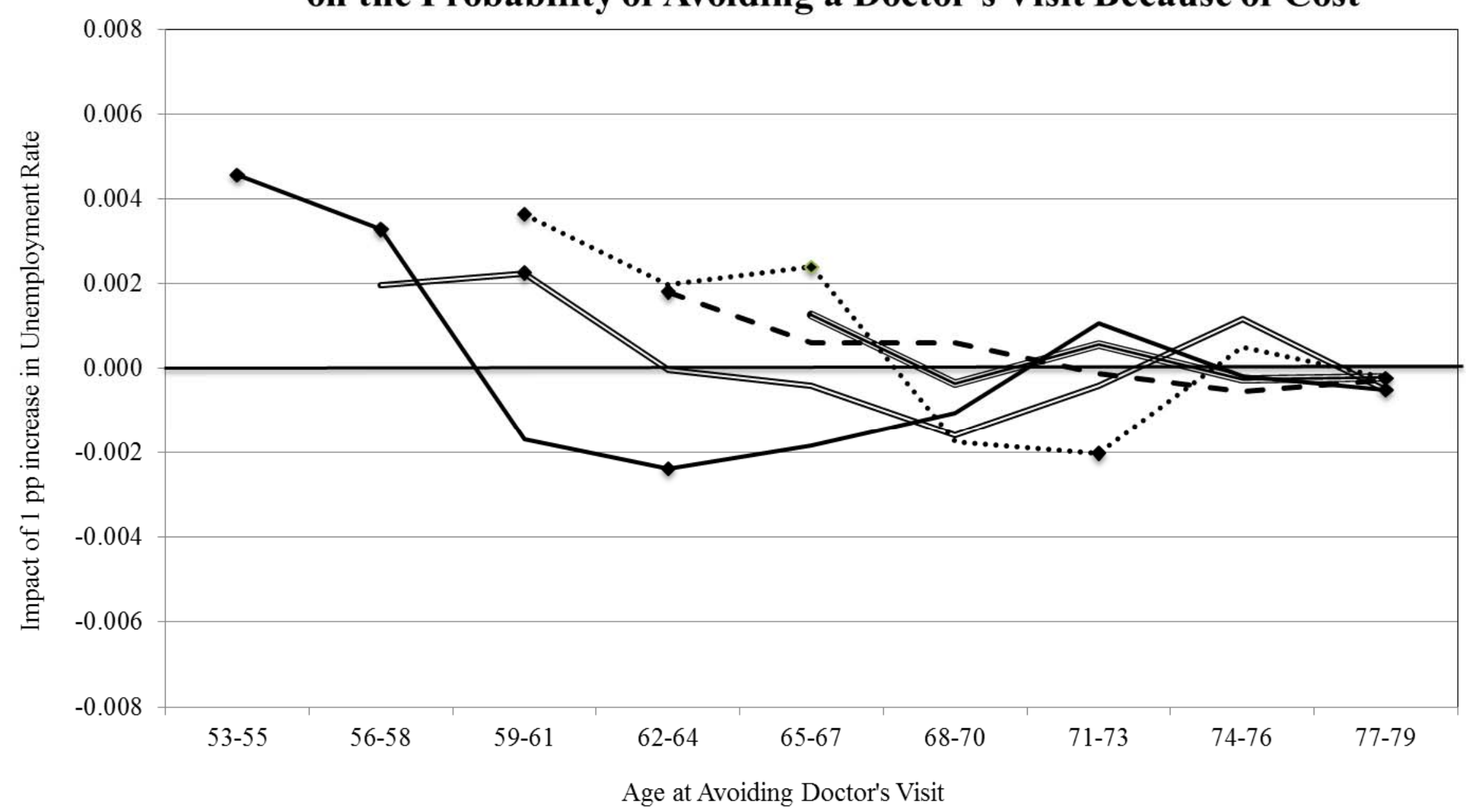

Unemployment Rate Measured at Age:

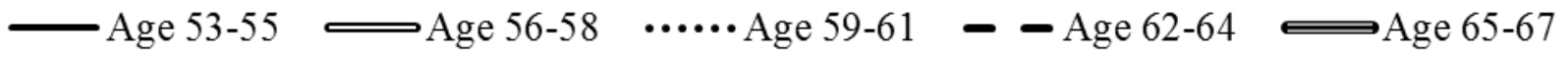


Figure 5: Impact of Unemployment Rate at Various Ages on the Probability of Having Any Health Insurance

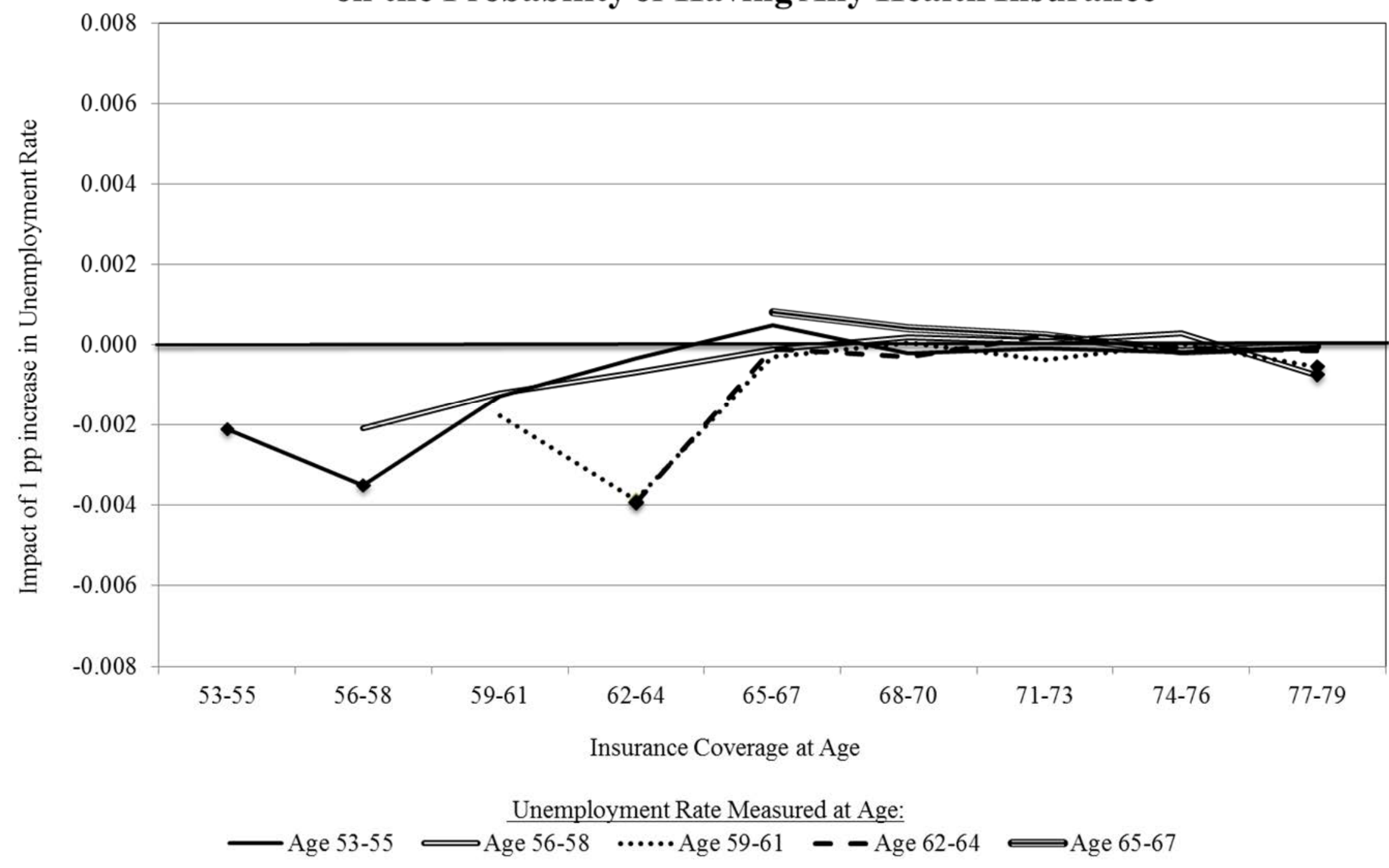

note: diamonds represent statistically significant (at the $5 \%$ level) estimates. 
Figure 6: Impact of Unemployment Rate at Various Ages on the Probability of Having Private Health Insurance

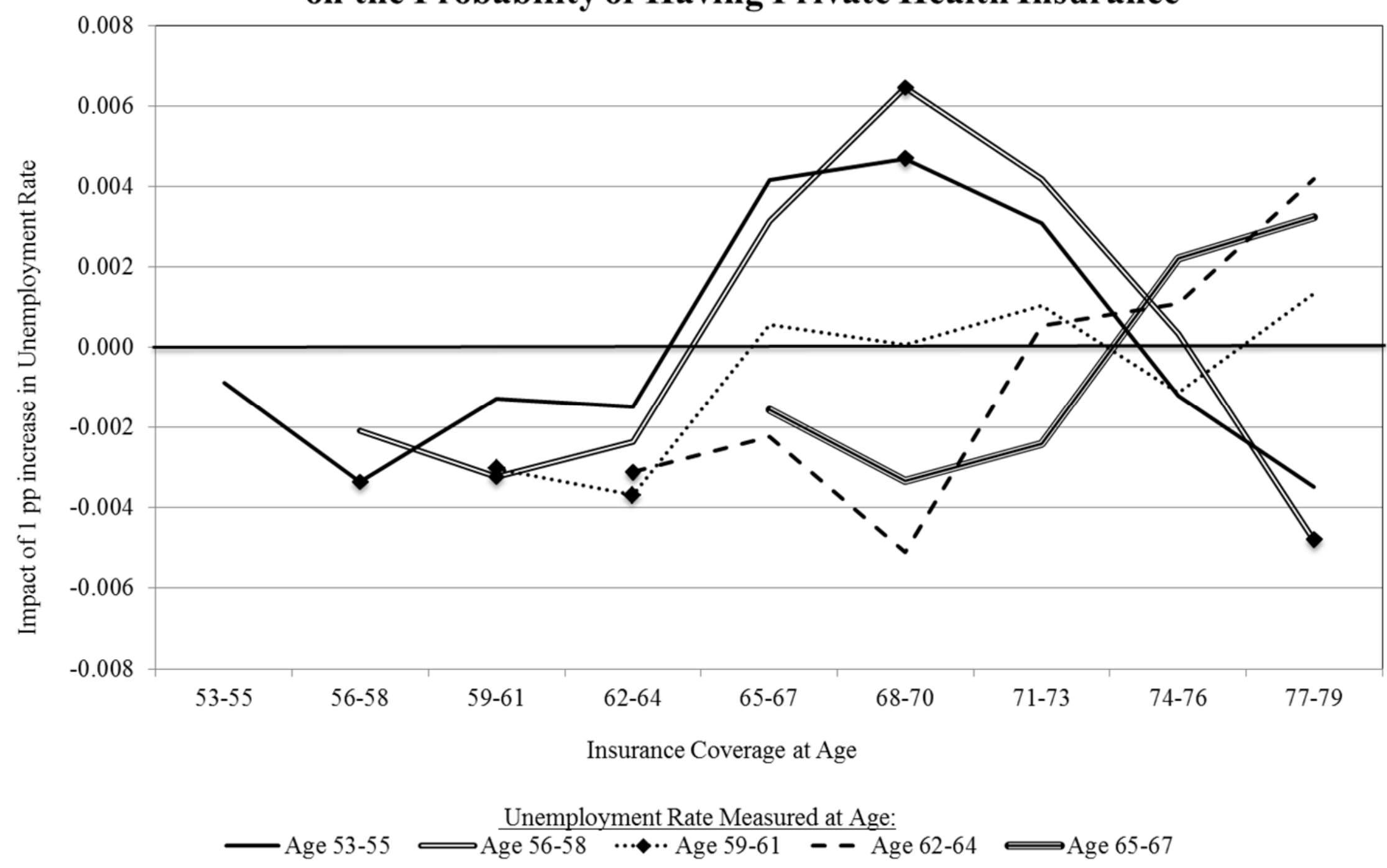

note: diamonds represent statistically significant (at the $5 \%$ level) estimates. 
Figure 7: Impact of Unemployment Rate at Various Ages on the Probability of Subsequent Employment

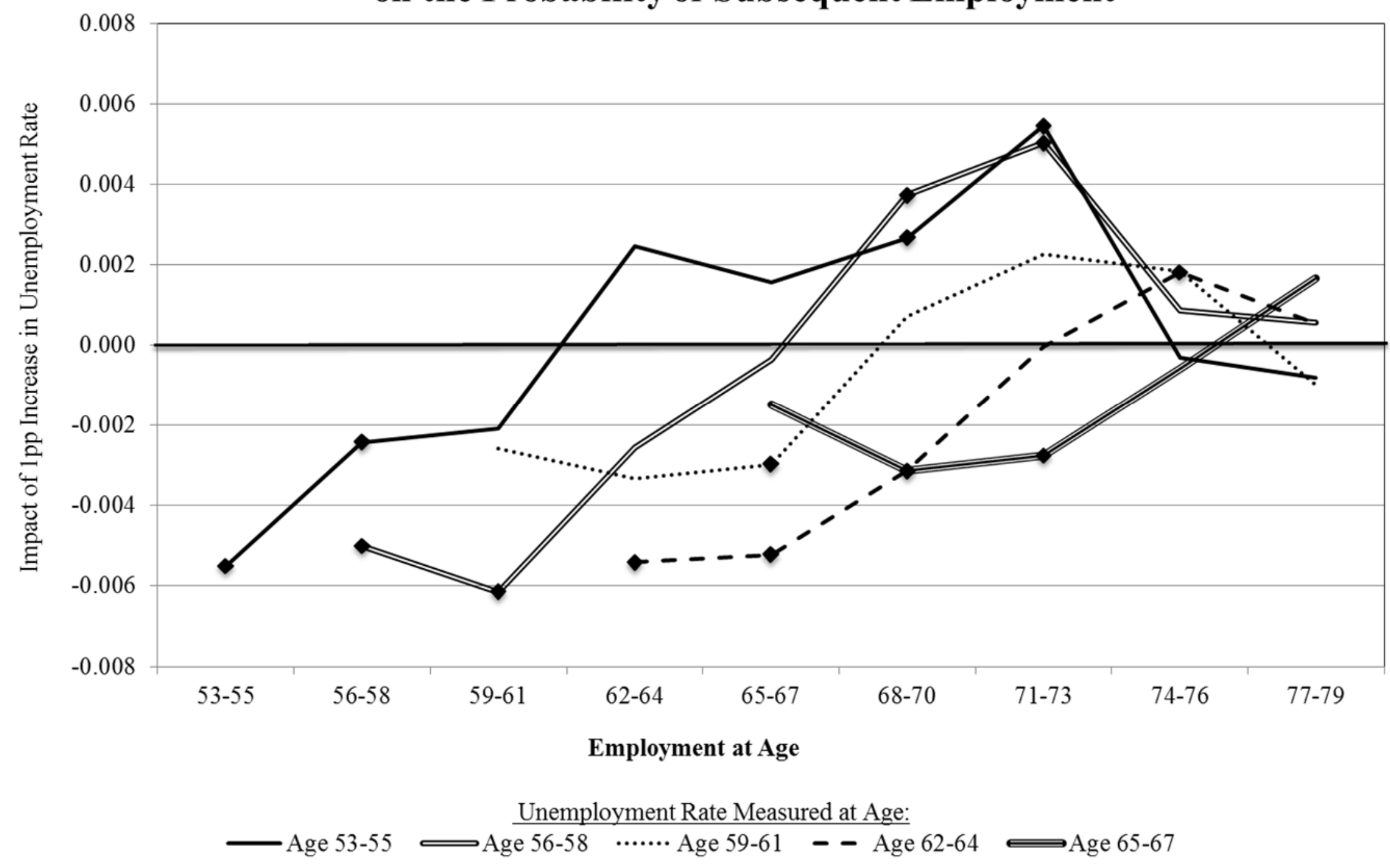

note: diamonds represent statistically significant (at the 5\% level) estimates. 
Appendix Table 1: Survival Probabilities

\begin{tabular}{|c|c|c|c|c|c|c|c|c|c|c|c|c|c|}
\hline \multirow{2}{*}{$\begin{array}{c}\text { Exact } \\
\text { Age }\end{array}$} & \multicolumn{13}{|c|}{ Survival Through Age: } \\
\hline & 55 & 56 & 57 & 58 & 59 & 60 & 61 & 62 & 63 & 64 & 65 & 66 & 67 \\
\hline 55 & 0.990 & 0.980 & 0.969 & 0.957 & 0.945 & 0.932 & 0.918 & 0.903 & 0.888 & 0.872 & 0.855 & 0.838 & 0.820 \\
\hline 56 & & 0.989 & 0.978 & 0.966 & 0.954 & 0.940 & 0.926 & 0.911 & 0.896 & 0.880 & 0.863 & 0.845 & 0.827 \\
\hline 57 & & & 0.989 & 0.976 & 0.964 & 0.950 & 0.936 & 0.920 & 0.905 & 0.889 & 0.871 & 0.853 & 0.834 \\
\hline 58 & & & & 0.987 & 0.975 & 0.961 & 0.946 & 0.930 & 0.914 & 0.898 & 0.880 & 0.862 & 0.843 \\
\hline 59 & & & & & 0.987 & 0.973 & 0.958 & 0.942 & 0.925 & 0.909 & 0.890 & 0.872 & 0.852 \\
\hline 60 & & & & & & 0.986 & 0.971 & 0.954 & 0.938 & 0.921 & 0.902 & 0.883 & 0.864 \\
\hline 61 & & & & & & & 0.985 & 0.968 & 0.951 & 0.934 & 0.916 & 0.896 & 0.876 \\
\hline 62 & & & & & & & & 0.983 & 0.966 & 0.949 & 0.930 & 0.910 & 0.890 \\
\hline 63 & & & & & & & & & 0.983 & 0.965 & 0.945 & 0.926 & 0.905 \\
\hline 64 & & & & & & & & & & 0.982 & 0.962 & 0.942 & 0.921 \\
\hline 65 & & & & & & & & & & & 0.980 & 0.959 & 0.938 \\
\hline 66 & & & & & & & & & & & & 0.979 & 0.957 \\
\hline 67 & & & & & & & & & & & & & 0.978 \\
\hline \multicolumn{14}{|l|}{68} \\
\hline \multicolumn{14}{|l|}{69} \\
\hline \multicolumn{14}{|l|}{70} \\
\hline \multicolumn{14}{|l|}{71} \\
\hline \multicolumn{14}{|l|}{72} \\
\hline \multicolumn{14}{|l|}{73} \\
\hline \multicolumn{14}{|l|}{74} \\
\hline \multicolumn{14}{|l|}{75} \\
\hline \multicolumn{14}{|l|}{76} \\
\hline \multicolumn{14}{|l|}{77} \\
\hline \multicolumn{14}{|l|}{78} \\
\hline 79 & & & & & & & & & & & & & \\
\hline
\end{tabular}


Appendix Table 1 (continued): Survival Probabilities

\begin{tabular}{|c|c|c|c|c|c|c|c|c|c|c|c|c|}
\hline \multirow[b]{2}{*}{ Exact Age } & \multicolumn{12}{|c|}{ Survival Through Age: } \\
\hline & 68 & 69 & 70 & 71 & 72 & 73 & 74 & 75 & 76 & 77 & 78 & 79 \\
\hline 55 & 0.800 & 0.780 & 0.759 & 0.737 & 0.714 & 0.689 & 0.665 & 0.639 & 0.613 & 0.585 & 0.557 & 0.528 \\
\hline 56 & 0.807 & 0.786 & 0.765 & 0.743 & 0.719 & 0.695 & 0.669 & 0.644 & 0.617 & 0.589 & 0.561 & 0.531 \\
\hline 57 & 0.814 & 0.794 & 0.772 & 0.749 & 0.725 & 0.700 & 0.675 & 0.649 & 0.622 & 0.594 & 0.565 & 0.535 \\
\hline 58 & 0.822 & 0.801 & 0.779 & 0.756 & 0.732 & 0.707 & 0.681 & 0.654 & 0.627 & 0.598 & 0.569 & 0.539 \\
\hline 59 & 0.832 & 0.810 & 0.788 & 0.764 & 0.740 & 0.714 & 0.688 & 0.661 & 0.633 & 0.604 & 0.575 & 0.544 \\
\hline 60 & 0.843 & 0.821 & 0.799 & 0.775 & 0.750 & 0.724 & 0.697 & 0.670 & 0.641 & 0.612 & 0.582 & 0.551 \\
\hline 61 & 0.855 & 0.833 & 0.810 & 0.786 & 0.761 & 0.734 & 0.707 & 0.679 & 0.651 & 0.621 & 0.591 & 0.559 \\
\hline 62 & 0.868 & 0.846 & 0.823 & 0.798 & 0.772 & 0.746 & 0.718 & 0.690 & 0.661 & 0.630 & 0.600 & 0.568 \\
\hline 63 & 0.883 & 0.860 & 0.836 & 0.811 & 0.785 & 0.758 & 0.730 & 0.701 & 0.672 & 0.641 & 0.610 & 0.577 \\
\hline 64 & 0.898 & 0.875 & 0.851 & 0.826 & 0.799 & 0.771 & 0.743 & 0.714 & 0.684 & 0.652 & 0.620 & 0.587 \\
\hline 65 & 0.915 & 0.892 & 0.867 & 0.841 & 0.814 & 0.786 & 0.757 & 0.727 & 0.696 & 0.664 & 0.632 & 0.598 \\
\hline 66 & 0.934 & 0.910 & 0.885 & 0.858 & 0.830 & 0.801 & 0.772 & 0.741 & 0.710 & 0.678 & 0.644 & 0.610 \\
\hline 67 & 0.954 & 0.929 & 0.903 & 0.876 & 0.848 & 0.819 & 0.788 & 0.757 & 0.725 & 0.692 & 0.658 & 0.623 \\
\hline 68 & 0.976 & 0.951 & 0.924 & 0.896 & 0.867 & 0.837 & 0.806 & 0.775 & 0.742 & 0.708 & 0.673 & 0.637 \\
\hline 69 & & 0.974 & 0.947 & 0.919 & 0.889 & 0.858 & 0.826 & 0.794 & 0.760 & 0.725 & 0.690 & 0.653 \\
\hline 70 & & & 0.972 & 0.943 & 0.912 & 0.881 & 0.848 & 0.815 & 0.780 & 0.744 & 0.708 & 0.670 \\
\hline 71 & & & & 0.970 & 0.938 & 0.906 & 0.872 & 0.838 & 0.802 & 0.765 & 0.728 & 0.689 \\
\hline 72 & & & & & 0.967 & 0.934 & 0.899 & 0.864 & 0.827 & 0.789 & 0.750 & 0.710 \\
\hline 73 & & & & & & 0.965 & 0.929 & 0.893 & 0.855 & 0.815 & 0.775 & 0.734 \\
\hline 74 & & & & & & & 0.963 & 0.925 & 0.885 & 0.845 & 0.803 & 0.760 \\
\hline 75 & & & & & & & & 0.960 & 0.919 & 0.877 & 0.834 & 0.789 \\
\hline 76 & & & & & & & & & 0.957 & 0.913 & 0.868 & 0.822 \\
\hline 77 & & & & & & & & & & 0.954 & 0.907 & 0.858 \\
\hline 78 & & & & & & & & & & & 0.950 & 0.900 \\
\hline 79 & & & & & & & & & & & & 0.946 \\
\hline
\end{tabular}


Appendix Table 2: Impact of Unemployment Rates at Specific Ages on Survival Rates at Different Ages

\begin{tabular}{|c|c|c|c|c|c|c|c|c|c|c|c|c|}
\hline \multirow{2}{*}{$\begin{array}{l}\text { Unemp. } \\
\text { at Age: }\end{array}$} & \multicolumn{12}{|c|}{ Survival to Age: } \\
\hline & 55 & 56 & 57 & 58 & 59 & 60 & 61 & 62 & 63 & 64 & 65 & 66 \\
\hline \multirow[t]{2}{*}{55} & 0.0025 & 0.0061 & 0.0112 & 0.0131 & 0.0130 & 0.0132 & 0.0083 & 0.0070 & 0.0002 & -0.0045 & -0.0056 & -0.0012 \\
\hline & $(0.0021)$ & $(0.0030)$ & $(0.0044)$ & $(0.0051)$ & $(0.0053)$ & $(0.0065)$ & $(0.0074)$ & $(0.0076)$ & $(0.0086)$ & $(0.0089)$ & $(0.0104)$ & $(0.0115)$ \\
\hline \multirow[t]{2}{*}{56} & & 0.0043 & 0.0117 & 0.0121 & 0.0107 & 0.0101 & 0.0032 & 0.0038 & -0.0060 & -0.0122 & -0.0158 & -0.0148 \\
\hline & & $(0.0025)$ & $(0.0042)$ & $(0.0055)$ & $(0.0061)$ & $(0.0073)$ & $(0.0074)$ & $(0.0073)$ & $(0.0078)$ & $(0.0087)$ & $(0.0099)$ & $(0.0114)$ \\
\hline \multirow[t]{2}{*}{57} & & & 0.0068 & 0.0067 & 0.0066 & 0.0042 & -0.0018 & -0.0028 & -0.0118 & -0.0190 & -0.0227 & -0.0205 \\
\hline & & & $(0.0028)$ & $(0.0049)$ & $(0.0061)$ & $(0.0080)$ & $(0.0077)$ & $(0.0075)$ & $(0.0073)$ & $(0.0069)$ & $(0.0076)$ & $(0.0091)$ \\
\hline \multirow[t]{2}{*}{58} & & & & 0.0031 & 0.0051 & 0.0026 & -0.0062 & -0.0141 & -0.0217 & -0.0287 & -0.0298 & -0.0307 \\
\hline & & & & $(0.0026)$ & $(0.0041)$ & $(0.0059)$ & $(0.0068)$ & $(0.0075)$ & $(0.0084)$ & (0.0089) & $(0.0084)$ & $(0.0081)$ \\
\hline \multirow[t]{2}{*}{59} & & & & & 0.0088 & 0.0083 & 0.0027 & -0.0071 & -0.0167 & -0.0270 & -0.0272 & -0.0311 \\
\hline & & & & & $(0.0025)$ & (0.0039) & $(0.0057)$ & $(0.0072)$ & $(0.0088)$ & (0.0103) & $(0.0097)$ & $(0.0095)$ \\
\hline \multirow[t]{2}{*}{60} & & & & & & 0.0013 & 0.0003 & -0.0059 & -0.0099 & -0.0184 & -0.0186 & -0.0235 \\
\hline & & & & & & $(0.0020)$ & (0.0039) & $(0.0054)$ & $(0.0073)$ & $(0.0094)$ & $(0.0101)$ & (0.0107) \\
\hline \multirow[t]{2}{*}{61} & & & & & & & 0.0023 & 0.0003 & 0.0002 & -0.0077 & -0.0114 & -0.0143 \\
\hline & & & & & & & $(0.0022)$ & $(0.0037)$ & $(0.0059)$ & $(0.0080)$ & $(0.0090)$ & (0.0103) \\
\hline \multirow[t]{2}{*}{62} & & & & & & & & 0.0016 & 0.0054 & 0.0016 & 0.0022 & 0.0036 \\
\hline & & & & & & & & $(0.0025)$ & $(0.0040)$ & $(0.0058)$ & $(0.0059)$ & $(0.0073)$ \\
\hline \multirow[t]{2}{*}{63} & & & & & & & & & 0.0089 & 0.0100 & 0.0141 & 0.0193 \\
\hline & & & & & & & & & $(0.0025)$ & $(0.0047)$ & $(0.0050)$ & $(0.0068)$ \\
\hline \multirow[t]{2}{*}{64} & & & & & & & & & & 0.0039 & 0.0093 & 0.0160 \\
\hline & & & & & & & & & & $(0.0032)$ & $(0.0046)$ & $(0.0057)$ \\
\hline \multirow[t]{2}{*}{65} & & & & & & & & & & & 0.0062 & 0.0120 \\
\hline & & & & & & & & & & & $(0.0028)$ & $(0.0051)$ \\
\hline
\end{tabular}

Notes: coefficients and standard errors multiplied by 100 . 
Appendix Table 2 (continued): Impact of Unemployment Rates at Specific Ages on Survival Rates at Different Ages

\begin{tabular}{|c|c|c|c|c|c|c|c|c|c|c|c|c|c|}
\hline \multirow{2}{*}{$\begin{array}{l}\text { Unemp. } \\
\text { at Age: }\end{array}$} & \multicolumn{13}{|c|}{ Survival to Age: } \\
\hline & 67 & 68 & 69 & 70 & 71 & 72 & 73 & 74 & 75 & 76 & 77 & 78 & 79 \\
\hline \multirow[t]{2}{*}{55} & -0.0038 & -0.0066 & -0.0081 & -0.0079 & -0.0032 & 0.0013 & 0.0063 & 0.0064 & 0.0090 & 0.0129 & 0.0146 & 0.0173 & 0.0178 \\
\hline & $(0.0127)$ & $(0.0142)$ & $(0.0148)$ & $(0.0158)$ & $(0.0160)$ & $(0.0164)$ & $(0.0175)$ & $(0.0196)$ & $(0.0192)$ & $(0.0211)$ & $(0.0215)$ & $(0.0231)$ & $(0.0231)$ \\
\hline \multirow[t]{2}{*}{56} & -0.0165 & -0.0222 & -0.0215 & -0.0260 & -0.0227 & -0.0190 & -0.0146 & -0.0133 & -0.0133 & -0.0125 & -0.0136 & -0.0079 & -0.0053 \\
\hline & $(0.0133)$ & $(0.0140)$ & $(0.0148)$ & $(0.0157)$ & $(0.0153)$ & $(0.0155)$ & $(0.0165)$ & $(0.0173)$ & $(0.0173)$ & (0.0193) & (0.0198) & $(0.0203)$ & (0.0196) \\
\hline \multirow[t]{2}{*}{57} & -0.0205 & -0.0231 & -0.0236 & -0.0288 & -0.0273 & -0.0251 & -0.0201 & -0.0221 & -0.0209 & -0.0196 & -0.0208 & -0.0139 & -0.0112 \\
\hline & $(0.0107)$ & $(0.0114)$ & $(0.0121)$ & $(0.0135)$ & $(0.0129)$ & $(0.0133)$ & $(0.0134)$ & $(0.0143)$ & $(0.0152)$ & $(0.0167)$ & $(0.0176)$ & $(0.0183)$ & $(0.0192)$ \\
\hline \multirow[t]{2}{*}{58} & -0.0339 & -0.0355 & -0.0359 & -0.0474 & -0.0496 & -0.0507 & -0.0488 & -0.0499 & -0.0494 & -0.0503 & -0.0514 & -0.0474 & -0.0448 \\
\hline & $(0.0087)$ & $(0.0102)$ & (0.0108) & $(0.0114)$ & $(0.0114)$ & $(0.0116)$ & (0.0122) & $(0.0134)$ & $(0.0140)$ & $(0.0156)$ & $(0.0175)$ & $(0.0186)$ & (0.0197) \\
\hline \multirow[t]{2}{*}{59} & -0.0344 & -0.0332 & -0.0330 & -0.0447 & -0.0503 & -0.0511 & -0.0520 & -0.0510 & -0.0503 & -0.0497 & -0.0467 & -0.0451 & -0.0418 \\
\hline & $(0.0092)$ & $(0.0104)$ & $(0.0115)$ & (0.0128) & $(0.0141)$ & $(0.0143)$ & $(0.0147)$ & $(0.0151)$ & $(0.0157)$ & (0.0173) & (0.0193) & $(0.0200)$ & $(0.0214)$ \\
\hline \multirow[t]{2}{*}{60} & -0.0255 & -0.0235 & -0.0216 & -0.0273 & -0.0348 & -0.0352 & -0.0378 & -0.0365 & -0.0355 & -0.0389 & -0.0353 & -0.0339 & -0.0293 \\
\hline & (0.0104) & (0.0107) & $(0.0111)$ & $(0.0122)$ & $(0.0140)$ & $(0.0140)$ & $(0.0142)$ & $(0.0144)$ & (0.0157) & (0.0177) & (0.0190) & $(0.0200)$ & $(0.0215)$ \\
\hline \multirow[t]{2}{*}{61} & -0.0189 & -0.0142 & -0.0157 & -0.0170 & -0.0211 & -0.0232 & -0.0282 & -0.0288 & -0.0277 & -0.0276 & -0.0244 & -0.0258 & -0.0247 \\
\hline & $(0.0107)$ & $(0.0110)$ & $(0.0118)$ & (0.0118) & $(0.0131)$ & $(0.0131)$ & $(0.0134)$ & (0.0129) & $(0.0147)$ & $(0.0165)$ & $(0.0166)$ & $(0.0175)$ & (0.0192) \\
\hline \multirow[t]{2}{*}{62} & 0.0025 & 0.0064 & 0.0049 & 0.0029 & 0.0041 & 0.0036 & 0.0004 & -0.0030 & -0.0019 & -0.0015 & 0.0001 & -0.0070 & -0.0104 \\
\hline & $(0.0081)$ & $(0.0091)$ & (0.0098) & (0.0108) & $(0.0113)$ & (0.0108) & $(0.0121)$ & $(0.0124)$ & (0.0127) & $(0.0141)$ & (0.0139) & $(0.0150)$ & (0.0157) \\
\hline \multirow[t]{2}{*}{63} & 0.0208 & 0.0241 & 0.0221 & 0.0220 & 0.0254 & 0.0237 & 0.0231 & 0.0171 & 0.0143 & 0.0134 & 0.0127 & 0.0056 & -0.0035 \\
\hline & $(0.0086)$ & $(0.0095)$ & (0.0098) & (0.0103) & (0.0108) & (0.0107) & (0.0119) & $(0.0121)$ & (0.0125) & $(0.0132)$ & (0.0133) & $(0.0141)$ & (0.0139) \\
\hline \multirow[t]{2}{*}{64} & 0.0207 & 0.0239 & 0.0216 & 0.0234 & 0.0297 & 0.0254 & 0.0263 & 0.0182 & 0.0143 & 0.0114 & 0.0086 & 0.0009 & -0.0101 \\
\hline & $(0.0076)$ & $(0.0086)$ & $(0.0096)$ & (0.0103) & (0.0118) & (0.0124) & (0.0139) & $(0.0145)$ & $(0.0150)$ & (0.0157) & $(0.0155)$ & (0.0165) & $(0.0166)$ \\
\hline \multirow[t]{2}{*}{65} & 0.0175 & 0.0204 & 0.0157 & 0.0185 & 0.0234 & 0.0193 & 0.0186 & 0.0116 & 0.0092 & 0.0050 & -0.0009 & -0.0077 & -0.0183 \\
\hline & $(0.0071)$ & $(0.0082)$ & $(0.0096)$ & $(0.0109)$ & $(0.0132)$ & $(0.0147)$ & $(0.0159)$ & $(0.0169)$ & $(0.0181)$ & $(0.0193)$ & $(0.0195)$ & $(0.0201)$ & $(0.0207)$ \\
\hline
\end{tabular}

Notes: coefficients and standard errors multiplied by 100. 